\title{
Tidal changes in copepod abundance and maintenance of a summer Coscinodiscus bloom in the southern San Juan Channel, San Juan Islands, USA
}

\author{
Jeannette E. Zamon* \\ Department of Ecology and Evolutionary Biology, University of California, Irvine, California 92697-2525, USA
}

\begin{abstract}
Tidal currents interacting with complex topographies are common features of coastal environments. These interactions are hypothesized to have significant effects on local plankton distribution and abundance, and therefore on food availability to planktivorous fishes. The purpose of this study was to test the hypothesis that tidal currents interacting with an island archipelago create significant and predictable increases in copepod availability to planktivores. Copepod densities during flood and ebb tides were sampled weekly during July-October of 1995-1997. Copepods of the genera Pseudocalanus, Paracalanus, and Corycaeus were the numerically dominant zooplankton except during a bloom of dinoflagellates (Noctiluca spp.) in July 1996. At sampling locations within the main tidal current, median copepod densities were 47 to 252 copepods $\mathrm{m}^{-3}$ greater during flood tides. In contrast, median densities outside of the main current were not significantly different between tides. An unexpected finding was the presence of an abundant, large centric diatom (Coscinodiscus wailesii), which showed a prolonged bloom from early July through early October in all years. Changes in copepod abundance and maintenance of the $C$. wailesii bloom were most likely caused by the advection of copepod aggregations and nutrients from near or below the pycnocline in the Strait of Juan de Fuca. Conversion of copepod numerical abundance to biomass estimates suggests that tidal differences in copepod abundance could affect fish growth. The predictability of changes in copepod abundance may explain why tidal rips and jets are important feeding areas for planktivorous fishes, as well as for fish predators such as marine mammals and seabirds.
\end{abstract}

KEY WORDS: Tidal currents · Plankton · Copepods · Diatoms · Coscinodiscus · Prey availability · Energy subsidy $\cdot$ Strait of Juan de Fuca $\cdot$ San Juan Islands

Resale or republication not permitted without written consent of the publisher

\section{INTRODUCTION}

Interactions between tides and topographic relief are one class of phenomena that may enhance the availability of nutrients or plankton to marine food webs (Uda \& Ishino 1958, Johannes 1981, Wolanski \& Hamner 1988, Wolanski et al. 1988, St. John \& Pond 1992, St. John et al. 1992). Several authors have argued that interactions between tidal currents and plankton distributions create predictable changes in food availabil-

\footnotetext{
${ }^{*}$ Present address: Pacific Biological Station, 3190 Hammond Bay Road, Nanaimo, British Columbia V9R 5K6, Canada. E-mail: zamonj@pac.dfo-mpo.gc.ca
}

ity for planktivores (fishes: Hamner \& Hauri 1977, Bray 1981, Kingsford et al. 1991, Noda et al. 1994; seabirds: see review in Hunt et al. 1999; marine mammals: Brown et al. 1979). In particular, there is evidence that changes in copepod density will affect the distribution, feeding success, and growth of planktivorous fishes (Bray 1981, Hobson 1986, Kingsford et al. 1991, Shapiro \& Genin 1993, Noda et al. 1994, Anderson \& Sabado 1995). However, the few published studies where tidal differences in copepod abundance were measured are of short duration $(\leq 1 \mathrm{wk}$, except St. John et al. 1992) and do not have sample sizes large enough to test specifically for flood-ebb differences or to evaluate the biological significance of the measured differ- 
ences ( $\mathrm{n} \leq 7$ flood-ebb pairs; Alldredge \& Hamner 1980, Gagnon \& LaCroix 1982, Leichter et al. 1998). The objectives of this study were (1) to determine whether significant differences between copepod abundance on flood versus ebb tides existed, (2) to investigate the physical mechanisms responsible for any tidal changes in copepod abundance, and (3) to evaluate the potential biological significance of abundance differences to planktivorous fish.

\section{MATERIALS AND METHODS}

Study site. The San Juan archipelago in Washington State, USA, and its northward extension, the Gulf Islands of British Columbia, Canada, are known for strong tidal currents; complex horizontal and vertical structure; and large, diverse summertime aggregations of marine consumers, including fishes, marine birds, and marine mammals (Thomson 1981, Lewis \& Sharpe 1987). In the San Juan Islands, tidal patterns in the summer distributions of planktivorous juvenile fish (Pacific sandlance Ammodytes hexapterus and Pacific herring Clupea harengus) and fish predators (seabirds: Alcidae, Laridae; seals: Phoca vitulina) suggest that tidal cycles significantly affect local food web dynamics (Lewis \& Sharpe 1987, Zamon 2000, 2001). The study area was located in Cattle Pass, at the south entrance to San Juan Channel (Fig. 1). San Juan Channel is the narrowest of 3 channels connecting the Strait of Juan de Fuca in the south to the Strait of Georgia in the north (Thomson 1981). Flooding tidal currents in San Juan Channel flow from south to north; ebbing currents flow north to south.

Hydrographic measurements. Because different water masses are usually correlated with changes in plankton density, I determined the types of water present in and adjacent to San Juan Channel. The San Juan Channel is bounded by 2 bodies of stratified water: the Juan de Fuca Strait to the south and the Strait of Georgia to the north (Thomson 1981). It was possible, therefore, that stratified water could enter the study site from either the south or the north. It was also possible that Griffin Bay, a semi-enclosed bay immediately west of San Juan Channel, may have contained stratified water.

I sampled water profiles at 5 stations along a southto-north, $12 \mathrm{~km}$ transect from the Strait of Juan de Fuca and into the San Juan Channel (Fig. 2; station positions given in Appendix 1). Profiles were taken in late August or early September during spring and neap tides in 1996 and 1997. Therefore I was able to determine local water mass structure at the minimal (neap) and maximal (spring) tidal excursions. Each transect

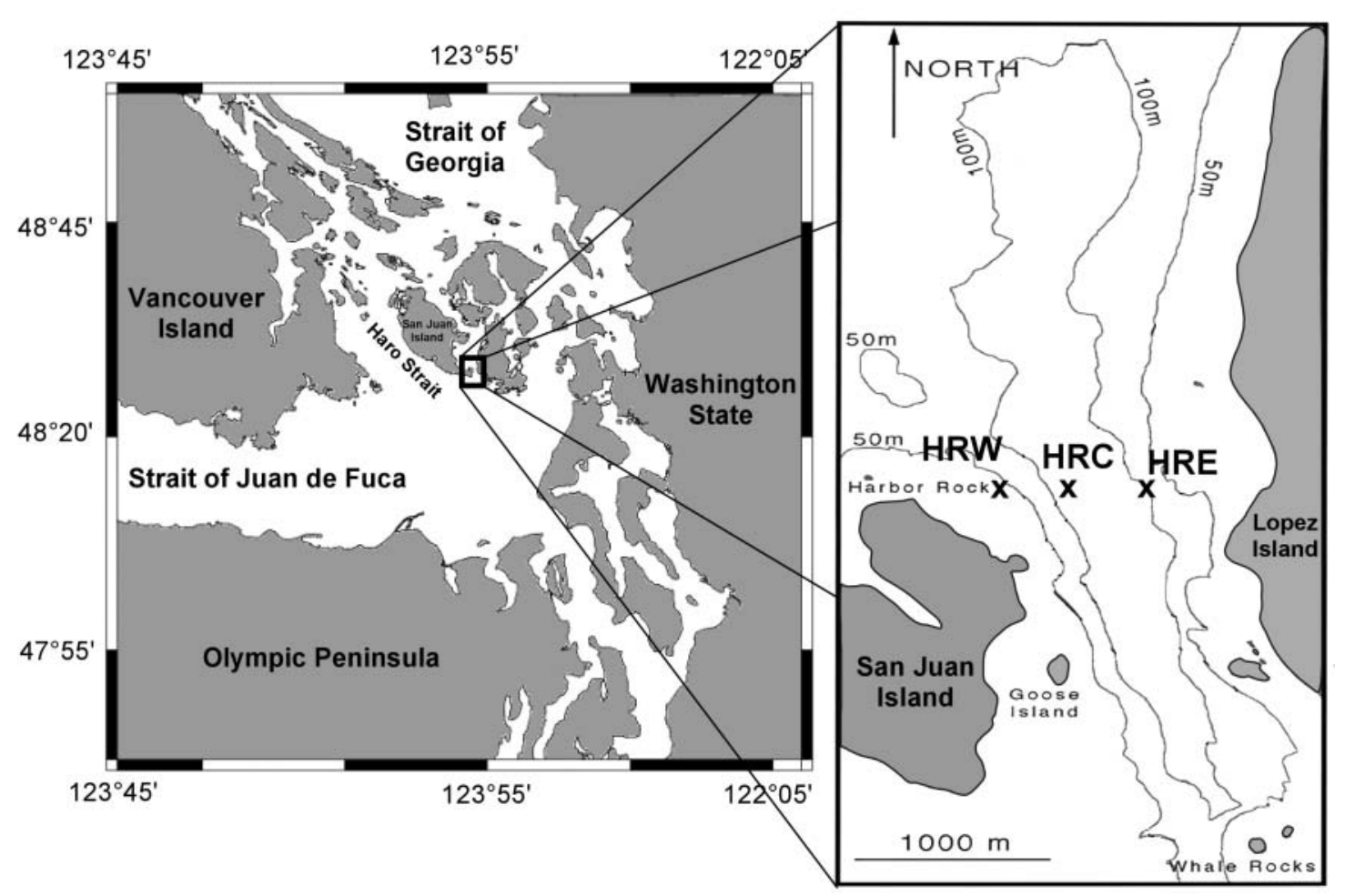

Fig. 1. Study site and net tow stations. Water properties and plankton densities were sampled in Cattle Pass, located in the southern San Juan Channel which runs between the eastern side of San Juan Island and the western side of Lopez Island in the San Juan archipelago. $\mathbf{x}$ : locations of plankton tows (HRE, HRC, and HRW) 


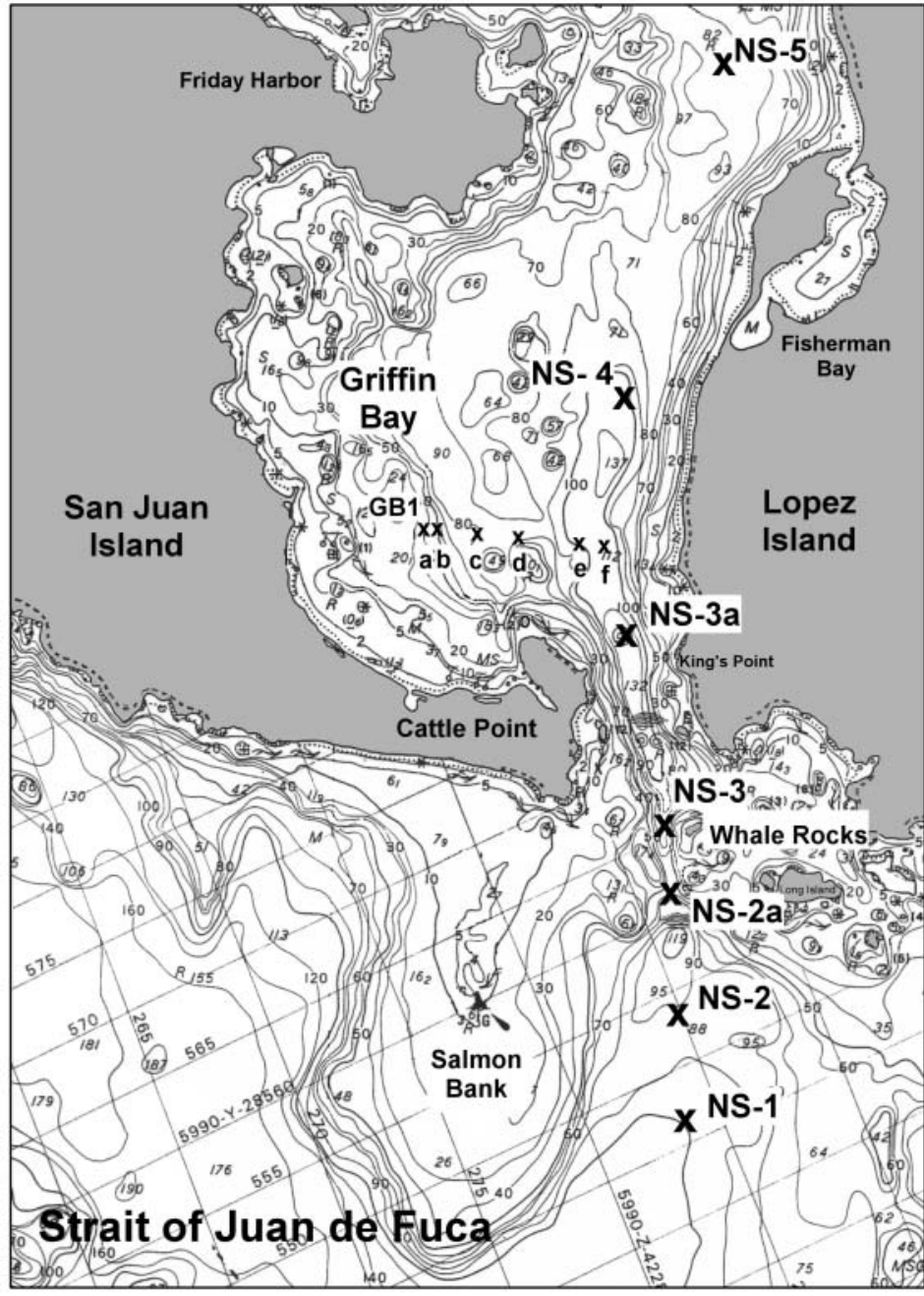

Fig. 2. Locations of temperature-salinity profiles taken during 1996 and 1997. Along-channel stations are indicated by the prefix 'NS', crosschannel stations are indicated by the prefix 'GB-1'. Latitude, longitude, and water depth for each station are given in Appendix 1 floor or to a maximum depth of $95 \mathrm{~m}$. Temperature and salinity data from the downward cast were averaged in $1 \mathrm{~m}$ bins. To visualize changes in water mass properties, I generated contour plots of water properties along a transect with an inverse-distancesquared gridding algorithm (Golden Software 1994).

Net sampling of plankton. Plankton were sampled from a single station in 1995, and then at each of 3 stations along a cross-channel transect in 1996 and 1997 (Fig. 1). Stn HRE ('Harbor Rock East', water depth $\sim 96 \mathrm{~m}$ ) was located westward of steep drop from 20 to $100 \mathrm{~m}$ in the area occupied by a strong tidal jet during flooding currents (surface velocities $>1.5 \mathrm{~m} \mathrm{~s}^{-1}$; Zamon 2000). Stn HRC ('Harbor Rock Central', water depth $\sim 133 \mathrm{~m}$ ) lay over the deepest part of the channel. Stn HRW ('Harbor Rock West', water depth $\sim 54 \mathrm{~m}$ ) was located on a relatively shallow shelf west of the main channel; Stn HRW was within a backwater eddy outside of the main north-south tidal flow. Each net tow began at the station's latitude and longitude, but the research vessel (a $4 \mathrm{~m}$ Boston Whaler) was allowed to drift with the prevailing current during each net tow.

To compare copepod densities between flooding and ebbing tides, I collected 3 replicate tows from each tide and each station on the same day ( 3 tows $\times 3$ stations $\times 2$ tides $=$ 18 tows per sampling day). Samples were collected after predicted current velocities in the second half of the tide fell below $1 \mathrm{~m} \mathrm{~s}^{-1}$, but before slack water. Pairs of flood and ebb tow sets were made once per week during July through October. I chose this sampling scheme because I wanted to sample while took approximately $1.5 \mathrm{~h}$ to complete. To determine whether stratified water existed in Griffin Bay, profiles were also taken along a west-to-east, $5.7 \mathrm{~km}$ transect from the $30 \mathrm{~m}$ contour in Griffin Bay to the eastern side of San Juan Channel (Fig. 2). This transect took approximately $30 \mathrm{~min}$ to complete.

I measured temperature and salinity versus depth using a Seabird SEACAT SBE-19 conductivity-temperature-depth instrument (CTD). The CTD was deployed and retrieved by hand with $1 / 4$ " (approx. $6 \mathrm{~mm}$ ) diameter, $150 \mathrm{~m}$ length line marked at $1 \mathrm{~m}$ intervals. The instrument was allowed to free-fall to the target depth (downward velocities $\sim 0.75-1.0 \mathrm{~m} \mathrm{~s}^{-1}$ ). The CTD casing had 4 acrylic 'fins' strapped to it with hose clamps; the fins kept the instrument falling with a straight trajectory. Profiles were made to 5-10 $\mathrm{m}$ above the sea currents were still moving, but when water masses and plankton densities were likely to be most different. I chose to sample the top $25 \mathrm{~m}$ during daylight hours because the most common planktivorous fish in the area, juvenile sandlance and juvenile herring, feed primarily at the surface during daylight hours (Winslade 1974, Hobson 1986, Field 1988, Batty et al. 1990, Arrhenius \& Hansson 1994, O'Reilly 1997).

I sampled plankton with a $0.25 \mathrm{~m}$ diameter, $333 \mu \mathrm{m}$ mesh ring net which had $3.6 \mathrm{~kg}$ of iron sash weights suspended below the cod end. The net type was chosen specifically to sample the smaller calanoid copepods (0.5 to $2 \mathrm{~mm})$, which are prey for juvenile sandlance and herring (Field 1988, Haegele 1997). The net was hand-hauled vertically from $25 \mathrm{~m}$ to the surface at a rate of 1.5 to $2 \mathrm{~m} \mathrm{~s}^{-1}$ while the vessel drifted at pre- 
vailing current speeds during retrievals. No flow meter was used in the opening because the meter would likely have reduced the capture efficiency of the net. Therefore, volume filtered per tow was calculated as

$$
\text { volume filtered in } \mathrm{m}^{3}=\pi(0.125 \mathrm{~m})^{2} 25 \mathrm{~m}
$$

Of 502 total tows 41 had measurable wire angles greater than zero; these 41 tows were excluded from the analysis to minimize bias due to unknown flow volumes in non-vertical tows.

Plankton were rinsed from the net with pressurized seawater dispensed from a hand-pumped, herbicidetype sprayer. Samples were preserved in $5 \%$ buffered formalin and filtered seawater immediately after collection and then sorted in the laboratory with a dissecting microscope. All specimens in each tow were sorted into general taxonomic categories and counted; no subsampling took place, except when densities of large centric diatoms or Noctiluca spp. cells exceeded $\sim 2000 \mathrm{~m}^{-3}$. In those cases, diatom or Noctiluca spp. cell abundances were subsampled from $200 \mathrm{ml}$ total volume with a $10 \mathrm{ml}$ Stempel pipette. Densities of diatoms and Noctiluca spp. from the subsample were extrapolated to the whole volume.

To determine whether any large-scale differences in plankton density occurred with depth, I compared shallow $(0$ to $25 \mathrm{~m}$ ) and deep ( 0 to $80 \mathrm{~m}$ ) tows. Three slack high and 3 slack low tides were sampled from well-mixed water at Stn HRE in 1997. Two tows were discarded because they became clogged with jellies (total of 34 tows). A strong pycnocline was present at Stn NS-2 during slack high tide, so it was necessary to compare plankton densities above and below the pycnocline in this area. I collected 5 tows from the pycnocline to the surface (shallow tows) and 5 tows from $95 \mathrm{~m}$ to the surface (deep tows) during slack high tides.

Statistical analyses. To compare relative numerical abundances of plankton from different taxonomic categories, I calculated the grand total of individuals captured in that taxonomic category in all tows from each station and year. I then divided the number of individuals in each category by the grand total of all plankton captured in that year. This generated relative frequencies for each taxonomic group captured by the net.

For all data, raw densities and natural logarithmtransformed densities were non-normally distributed with heterogeneous variances; therefore parametric tests comparing mean abundances were inappropriate. I used Wilcoxon matched-pair signed-rank tests to compare differences in median plankton densities from flood versus ebb tides at each station on the same sampling day. I selected the paired-sample test because it explicitly compared tides from the same day, thus reducing the confounding effects of daily and seasonal changes on plankton abundance.
I used a Mann-Whitney $U$-test to compare densities between shallow and deep tows. To determine whether or not there was significant between-station variation in plankton abundance, I used matched-pair signed-rank tests to make pair-wise comparisons between stations sampled on the same tide and day.

I used Kolmolgorov-Smirnov tests and MannWhitney $U$-tests for independent samples to determine whether there was significant interannual variation in the distribution of plankton densities from the same station. For these tests, data were unpaired and pooled for the same tide; for example, all tows taken in 1995 on the flood tide at Stn HRE were compared with all tows taken in 1996 on the flood tide at Stn HRE. Bonferroni corrections were applied to these multiple comparisons (10 possible comparisons for interannual comparisons, critical p-value $=0.005$ ) .

\section{RESULTS}

\section{Hydrographic description of southern San Juan Channel}

During slack low tides, stratified water was found on 1 of 4 spring tide series at the south of the entrance to San Juan Channel (Fig. 3a: Stns NS-1 and NS-2). The pycnocline appeared at approximately $70 \mathrm{~m}$ depth. During slack high spring tides from the same locations, stratified water appeared in all profiles; in all 4 cases, the pycnocline was found at depths between 30 and 40 $\mathrm{m}$ (Fig. 3b). Water in the upper layer was generally $10.0-11.5^{\circ} \mathrm{C}$ and $29.5-31.2 \mathrm{psu}$, indicating the influence of Fraser River outflow from the Strait of Georgia (Thomson 1981). Water below the pycnocline was generally $7.5-9.2^{\circ} \mathrm{C}$ and $32.0-33.3 \mathrm{psu}$; this deeper water resembled deep Juan de Fuca water in its properties (cf. Thomson 1981). Water with temperatures and salinities resembling deeper Juan de Fuca water was also found below $70 \mathrm{~m}$ just north of Whale Rocks (Stn NS-3), although a clear pycnocline in the upper water column was absent. Weakly stratified water was found in Griffin Bay (Fig. 4a,b) and north of Whale Rocks inside the San Juan Channel. The relatively unstratified condition in the upper $90 \mathrm{~m}$ inside San Juan Channel contrasts with the more stratified summertime conditions known from Haro and Rosario Straits (Thomson 1981).

The very abrupt transition from a strongly stratified condition in the Juan de Fuca Strait to a relatively unstratified condition in the southern San Juan Channel was not an artifact of contouring or sampling distance between stations. It was possible to visualize the strong pycnocline as a continuous, thin line of echo return by recording data from a single-beam, $6^{\circ}$ beamwidth, $120 \mathrm{kHz}$ echosounder while travelling on 
a)
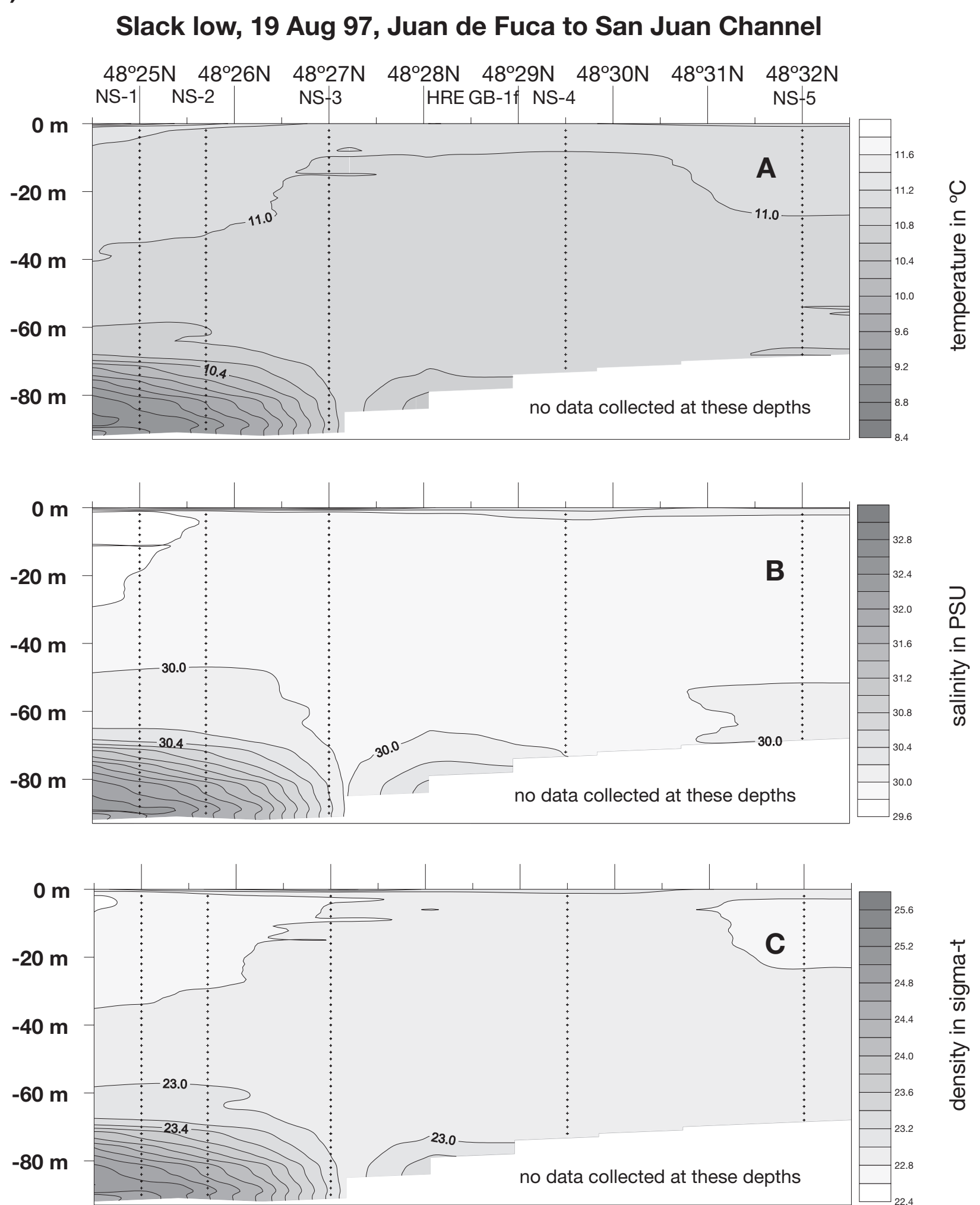

Fig. 3. (Above and following page.) South-to-north profile of Juan de Fuca and southern San Juan Channel, slack (a) low and (b) high spring tides. (A) Temperature, (B) salinity, and (C) density profiles. Vertical lines mark the locations of CTD Stns NS-1 through NS-5; the locations of net tows are indicated above the $x$-axis 
b)

b) Slack high, 19 Aug 97, Juan de Fuca to San Juan Channel
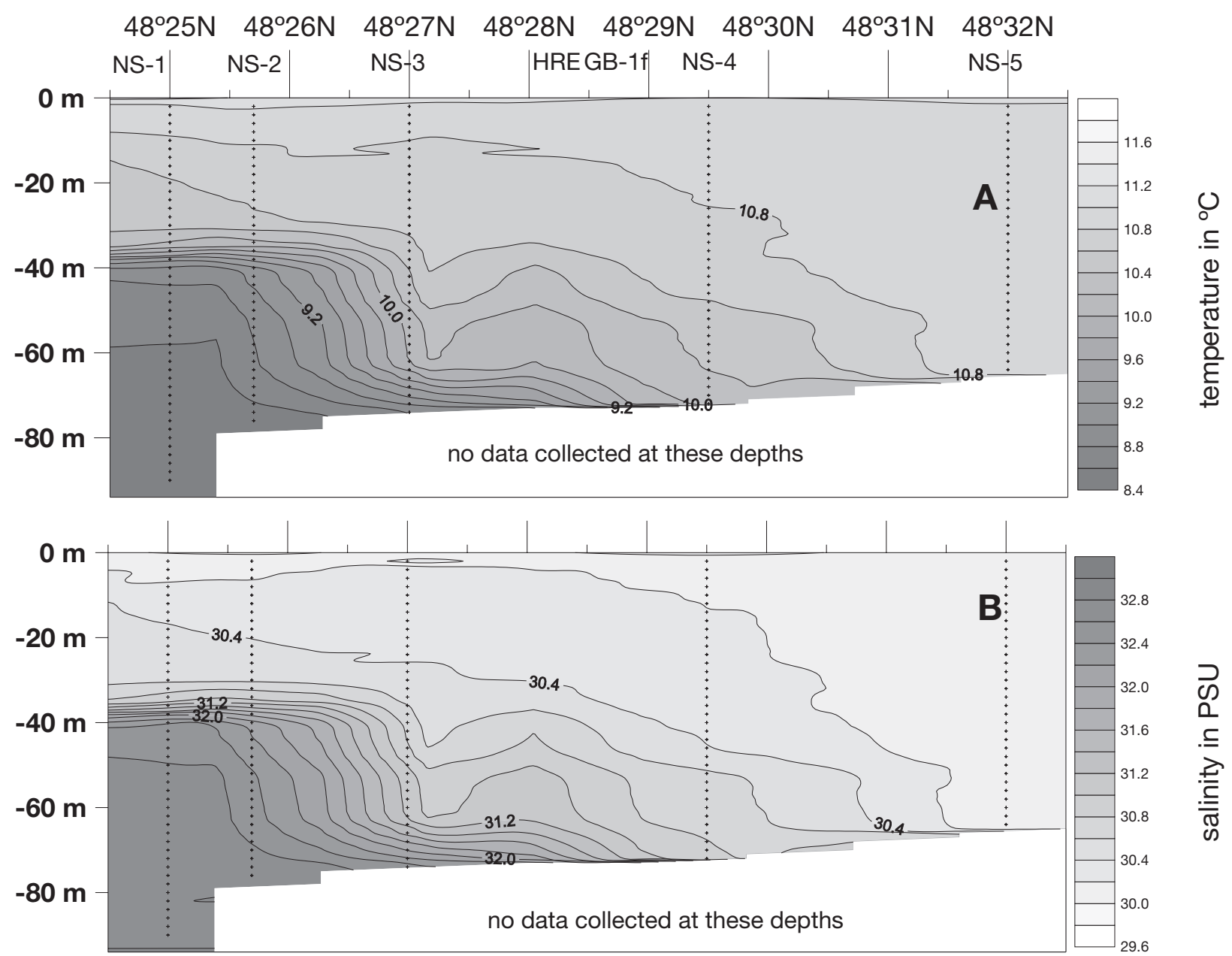

क

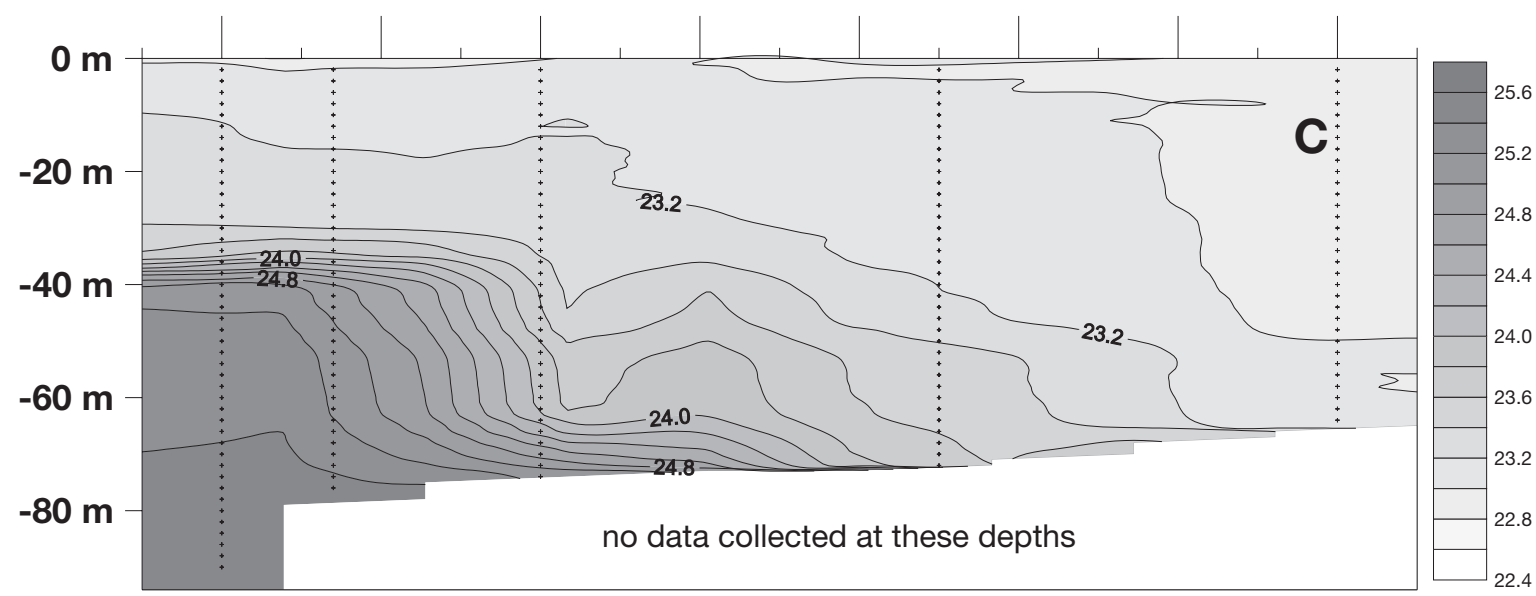

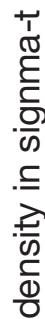

Fig. 3 (continued) 
a) Slack low, 26 Aug 96, San Juan Channel to Griffin Bay
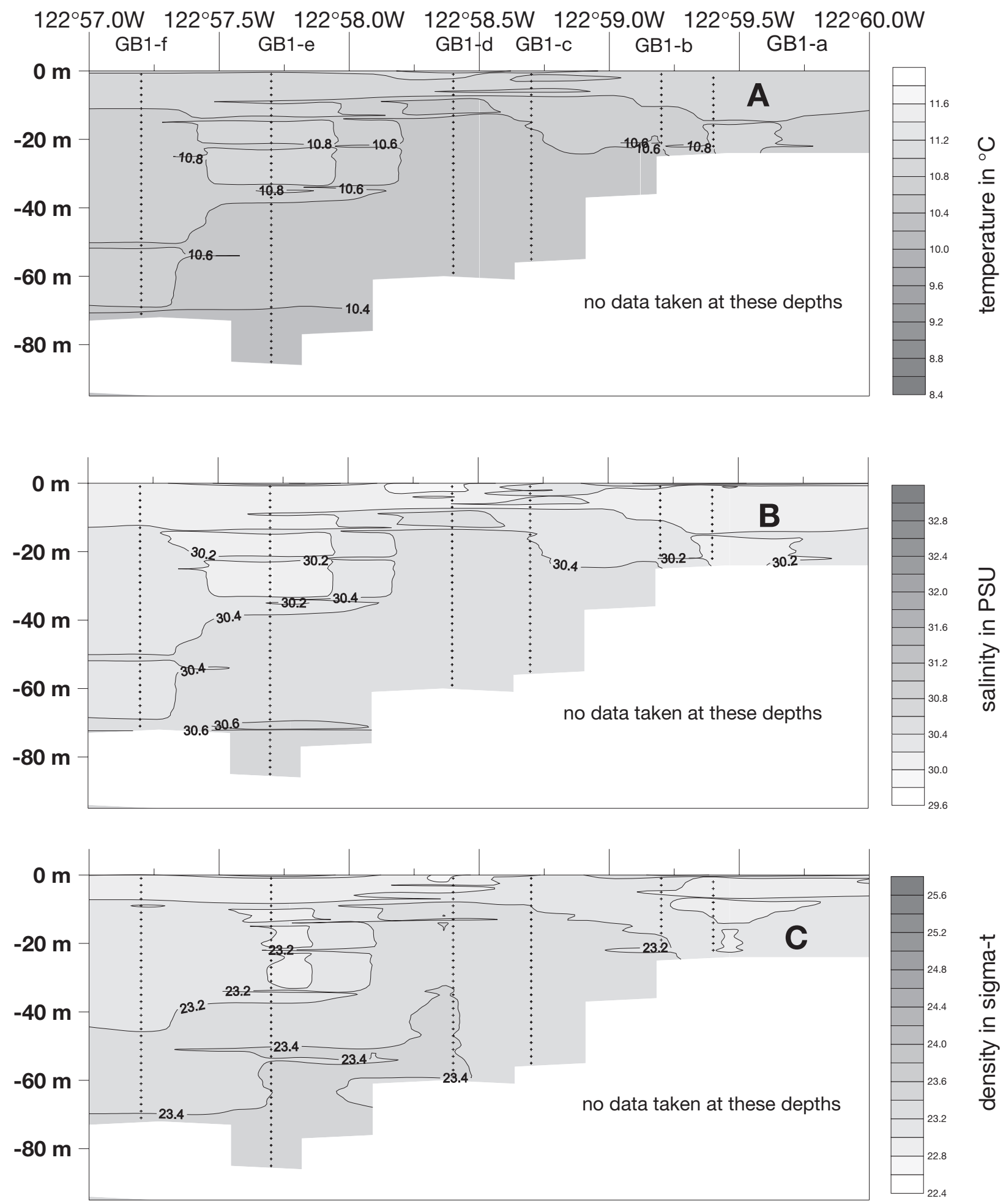

Fig. 4. (Above and following page.) East-to-west profile of Griffin Bay and southern San Juan Channel, slack (a) low and (b) high tides. (A) Temperature, (B) salinity, and (C) density profiles. Vertical lines mark the locations of Stns GB1-a through GB1-f. The inversions near Stns GB1-d and GB1-e are present in the uncontoured data and are not artifacts of the contouring algorithm 
b)
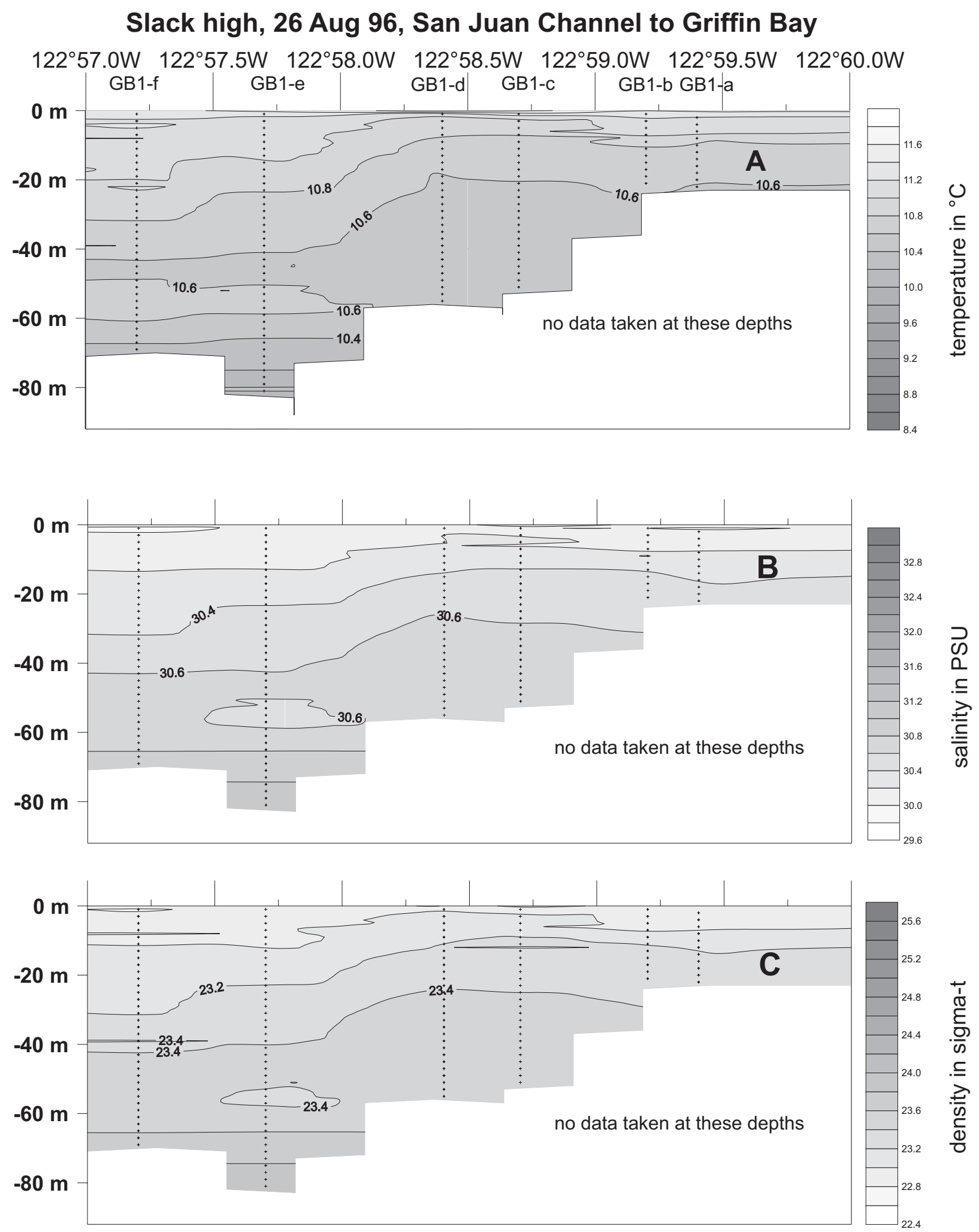

Fig. 4 (continued) 
the NS transect line (Fig. 5). CTD deployments confirmed that this thin line coincided with the pycnocline. Acoustic visualizations from tides on 27 August, 31 August, and 2 September 1997 confirmed the 20 to $40 \mathrm{~m}$ vertical displacements of the pycnocline between high and low tides just south of Cattle Pass, as well as the fact that a definitive pycnocline was always absent north of the channel constriction near Whale Rocks.

\section{Plankton community composition}

Taxonomic categories and their relative frequencies of abundance are listed in Table 1. Large centric diatoms and copepods were clearly the numerical dominants. Only centric diatoms (mostly Coscinodiscus wailesii) and small ( 1.5 mm) calanoid copepods (mostly Pseudocalanus, Paracalanus, and Acartia spp.) consistently accounted for $>5 \%$ of all plankton particles captured per year. The only exception to the numerical dominance of diatoms and copepods was a bloom of dinoflagellates (Noctiluca spp.) in July 1996. Densities of up to 4700 Noctiluca spp. $\mathrm{m}^{-3}$ were observed during the bloom. After the first week of August, however, large Noctiluca spp. were no longer captured in 1996. Noctiluca spp. were extremely rare in 1995 and 1997 samples. The rankings of the top 5 most numerous taxa did not differ among stations in 1996 and 1997, nor did relative frequencies between station pairs ever differ by more than $\pm 5 \%$.

\section{Tidal variation}

For the 2 stations located in the main tidal current, median copepod densities showed significant tidal dif-

Table 1. Relative numerical frequencies of plankton taxa

\begin{tabular}{|c|c|c|c|c|c|c|c|}
\hline Taxon & HRE 1995 & HRE 1996 & HRC 1996 & HRW 1996 & HRE 1997 & HRC 1997 & HRW 1997 \\
\hline Total plankters & $2.1 \times 10^{5}$ & $1.9 \times 10^{5}$ & $1.7 \times 10^{5}$ & $1.6 \times 10^{5}$ & $5.9 \times 10^{4}$ & $8.5 \times 10^{4}$ & $4.6 \times 10^{4}$ \\
\hline \multicolumn{8}{|l|}{ Large diatoms } \\
\hline Centric diatoms & 0.884 & 0.453 & 0.408 & 0.416 & 0.698 & 0.740 & 0.689 \\
\hline Other & 0.001 & 0.005 & 0.001 & 0.006 & 0.002 & 0.001 & 0.002 \\
\hline \multicolumn{8}{|l|}{ Copepods } \\
\hline Calanoid & 0.049 & 0.271 & 0.326 & 0.275 & 0.125 & 0.098 & 0.120 \\
\hline Cyclopoid & 0.023 & 0.026 & 0.031 & 0.045 & 0.046 & 0.032 & 0.060 \\
\hline Harpacticoid & $<0.001$ & $<0.001$ & $<0.001$ & 0.001 & 0.001 & $<0.001$ & $<0.001$ \\
\hline Noctiluca spp. & $<0.001$ & 0.142 & 0.108 & 0.141 & 0.023 & 0.021 & 0.024 \\
\hline Podon spp. & 0.004 & 0.006 & 0.007 & 0.007 & 0.029 & 0.031 & 0.034 \\
\hline \multicolumn{8}{|l|}{ Gelatinous plankters } \\
\hline Larvaceans & 0.008 & 0.025 & 0.028 & 0.031 & 0.022 & 0.014 & 0.013 \\
\hline Chaetognaths & 0.001 & 0.006 & 0.006 & 0.005 & 0.001 & 0.001 & 0.001 \\
\hline Pleurobrachia bachei & $<0.001$ & 0.004 & 0.005 & 0.006 & 0.001 & 0.001 & 0.001 \\
\hline Siphonophores and cnidarians & 0.011 & 0.020 & 0.018 & 0.014 & 0.008 & 0.009 & 0.008 \\
\hline \multicolumn{8}{|l|}{ Amphipods } \\
\hline Hyperiid amphipods & 0.001 & 0.006 & 0.010 & 0.008 & 0.002 & 0.001 & 0.002 \\
\hline Gammariid amphipods & $<0.001$ & $<0.001$ & $<0.001$ & $<0.001$ & $<0.001$ & $<0.001$ & $<0.001$ \\
\hline Evadne spp. & 0.001 & $<0.001$ & 0.001 & 0.001 & 0.003 & 0.003 & $<0.003$ \\
\hline Pteropods & $<0.001$ & $<0.001$ & 0.001 & 0.001 & $<0.001$ & $<0.001$ & $<0.001$ \\
\hline Polychaetes & 0.001 & $<0.001$ & $<0.001$ & $<0.001$ & $<0.001$ & $<0.001$ & 0.004 \\
\hline Ostracods & $<0.001$ & $<0.001$ & $<0.001$ & $<0.001$ & $<0.001$ & $<0.001$ & $<0.001$ \\
\hline Eggs & 0.002 & 0.004 & 0.004 & 0.005 & 0.008 & 0.005 & 0.007 \\
\hline \multicolumn{8}{|l|}{ Invertebrate larvae } \\
\hline Barnacle nauplius & 0.008 & 0.020 & 0.022 & 0.026 & 0.016 & 0.014 & 0.018 \\
\hline Cyprid & $<0.001$ & 0.001 & 0.001 & 0.001 & $<0.001$ & $<0.001$ & $<0.001$ \\
\hline Pluteus & 0.001 & $<0.001$ & $<0.001$ & $<0.001$ & $<0.001$ & $<0.001$ & $<0.001$ \\
\hline Furcilia & 0.001 & 0.005 & 0.006 & 0.007 & 0.004 & 0.004 & 0.007 \\
\hline Zooea & 0.001 & 0.003 & 0.003 & 0.003 & 0.002 & 0.002 & 0.004 \\
\hline Megalopae & $<0.001$ & $<0.001$ & 0.001 & $<0.001$ & 0.004 & 0.004 & 0.001 \\
\hline Other invertebrates & $<0.001$ & $<0.001$ & $<0.001$ & $<0.001$ & $<0.001$ & $<0.001$ & $<0.001$ \\
\hline Ascidian larvae & $<0.001$ & $<0.001$ & 0 & $<0.001$ & $<0.001$ & $<0.001$ & $<0.001$ \\
\hline Fish larvae & $<0.001$ & $<0.001$ & $<0.001$ & $<0.001$ & $<0.001$ & $<0.001$ & $<0.001$ \\
\hline Terrestrial arthropod & $<0.001$ & $<0.001$ & $<0.001$ & $<0.001$ & $<0.001$ & 0 & $<0.001$ \\
\hline
\end{tabular}




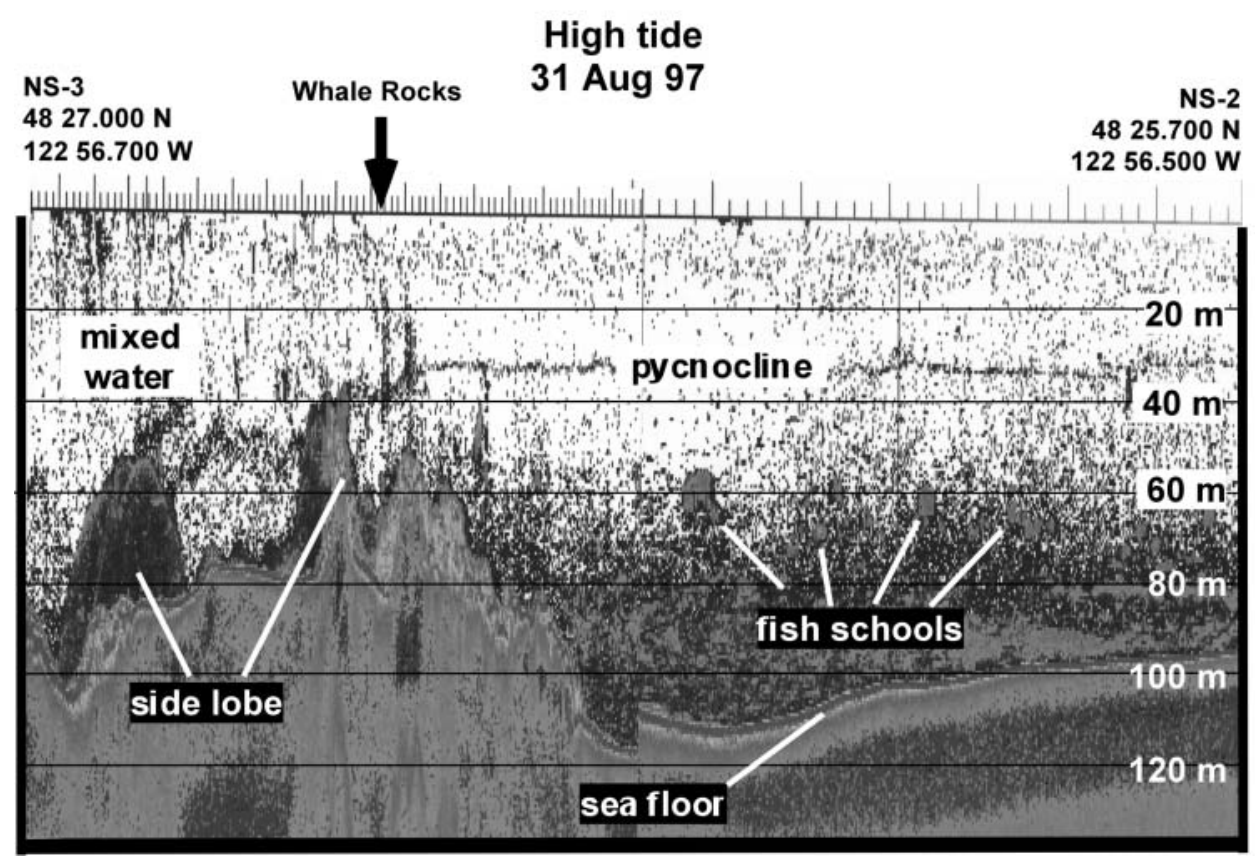

Fig. 5. Water mass structure during high tide at the interface between well-mixed water and stratified water, Whale Rocks, south entrance to San Juan Channel. The location of the pycnocline, visible in this picture as a thin line of echo return at about $37 \mathrm{~m}$, was confirmed with deployment of a CTD. This type of visualization was used to map the vertical and horizontal location of the pycnocline and to target net samples above and below the pycnocline. The minimum channel depth at Whale Rocks is approxi-

mately $80 \mathrm{~m}$; echo returns give the false impression of a shallow sill because side lobes return off adjacent channel walls

ferences in 4 of 5 cases: densities were significantly higher on flood tides in all years at Stn HRE and in 1997 at Stn HRC (Fig. 6a-c, Table 2). There was a tendency to have higher densities at Stn HRC for 1996, although the trend was not significant $(p=0.272)$. For the station located outside of the main tidal current (Stn HRW), densities between tides were not significantly different in either 1996 or 1997.

The presence of a very large centric diatom (Coscinodiscus wailesii) was an unexpected and striking feature of the plankton near Cattle Pass in all 3 years (Table 1). Within the main tidal current, C. wailesii densities were significantly higher on the incoming tide in 1995 and 1997, but not in 1996. There were no tidal differences at either within-current station during 1996 (Fig. 7a-c, Table 3). Outside of the main tidal current (HRW), there was no significant difference between flood and ebb C. wailesii abundance.

\section{Depth variation}

In weakly stratified water north of Whale Rocks, copepod densities showed no significant differences

Table 2. Analysis of flood versus ebb differences in copepod densities. Tows with non-zero wire angles were excluded from the analyses. p-values in italics are statistically significant

\begin{tabular}{|lccccc|}
\hline Stn & Year & $\begin{array}{c}\text { No. of valid flood-ebb } \\
\text { comparisons }\end{array}$ & $\begin{array}{c}\text { p-value of } \\
\text { signed-rank test }\end{array}$ & $\begin{array}{c}\text { Median density difference } \\
\text { for flood vs. ebb } \\
\text { (copepods m }{ }^{-3} \text { ) }\end{array}$ & $\begin{array}{c}\text { Percent of comparisons } \\
\text { where median flood } \\
\text { density }>\text { median ebb density }\end{array}$ \\
\hline HRE & 1995 & 16 & 0.004 & +62 & 81 \\
& 1996 & 11 & 0.008 & +251 & 91 \\
& 1997 & 11 & 0.028 & +47 & 73 \\
HRC & 1996 & 12 & 0.272 & +282 & 97 \\
& 1997 & 11 & 0.006 & -40 & 33 \\
HRW & 1996 & 12 & 0.695 & +11 & 64 \\
\hline
\end{tabular}


between deep and shallow tows on either slack low or slack high tides at Stn HRE (Fig. 8, Mann-Whitney $U$-test: $\mathrm{p}>0.35$ for both tides). In contrast, copepods in the stratified water at Stn NS-2 were significantly more abundant in deep tows (Table 4, Mann-Whitney U-test: $\mathrm{p}<0.01)$. For Coscinodiscus wailesii, there were no significant differences between deep and shallow densities during slack low tide at Stn HRE (Fig. 8, Mann-Whitney U-test: $\mathrm{p}=0.222$ ), but they were significantly more abundant in deep tows on slack high tides (MannWhitney $U$-test: $\mathrm{p}=0.013$ ). In stratified water, no significant differences were found in comparisons of diatom densities in shallow versus deep tows (Table 4, Mann-Whitney $U$-test: p > 0.2).

\section{Between-station and interannual variation}

During flood tides, median copepod densities tended to be less for Stn HRW than for either Stn HRC or Stn HRE in 1996 ( $p=0.026$ and 0.06, respectively). No other significant station-station density differences occurred during 1996 or 1997 ( $p>0.10$ in all other comparisons).

Copepod densities were variable but exhibited no obvious seasonal trends within years during the months of July through October. However, Fig. 6 shows that copepods were significantly more abundant at all stations in 1996 than in either 1995 or 1997 (Kolmolgorov-Smirnov tests and Mann-Whitney $U$-tests, all pairwise comparisons significant at $\mathrm{p}<0.001$ ). Copepod abundances in 1995 and 1997 were not significantly different (KolmolgorovSmirnov tests and Mann-Whitney $U$-tests, p > 0.09 for flood and ebb). The increased copepod abundance in 1996 appeared to be a community-wide effect: mean densities of Pseudocalanus, Paracalanus, Corycaeus anglicus, and Acartia spp. were all approximately 4 times greater in 1996 than in 1997.

For Coscinodiscus wailesii, signed-rank tests showed no differences in median densities between Stns HRE and HRC in 1996 or 1997. In contrast, median densities at Stn HRW were significantly less than at both Stns HRC and HRE during flood tides in 1997 ( $\mathrm{p}<0.05$ ). Median densities at Stn HRW were lower than at Stn HRE during ebb tides in 1996 ( $\mathrm{p}=$ 0.026). Otherwise, there were no station-to-station differences in 1996.

During this study, Coscinodiscus wailesii abundance increased during early July, and high cell densities persisted through August, September, and early October (Fig. 7a-c). Abundance appeared to decrease during mid- to late October in 1995 and
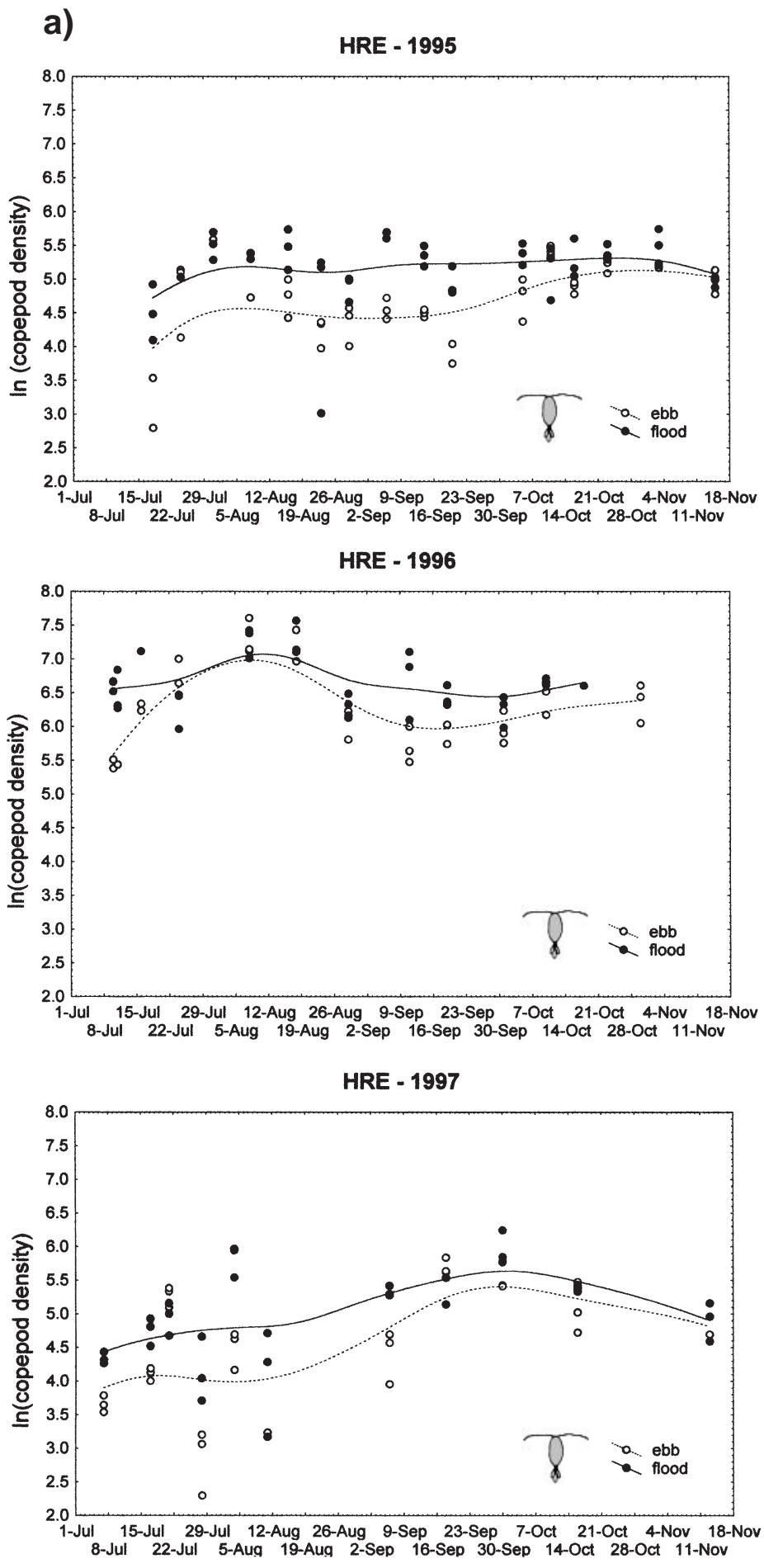

Fig. 6. (Above and following page.) Copepod density versus date. (a) Stn HRE, (b) Stn HRC, and (c) Stn HRW. Raw densities of copepods per cubic meter were transformed to the natural logarithm of raw densities. No tows contained zero copepods. Best-fit lines were drawn using the least-squares method. The lines help visualize seasonal trends and differences in central tendencies between flood and ebb tides, but they have no other statistical significance 
b)

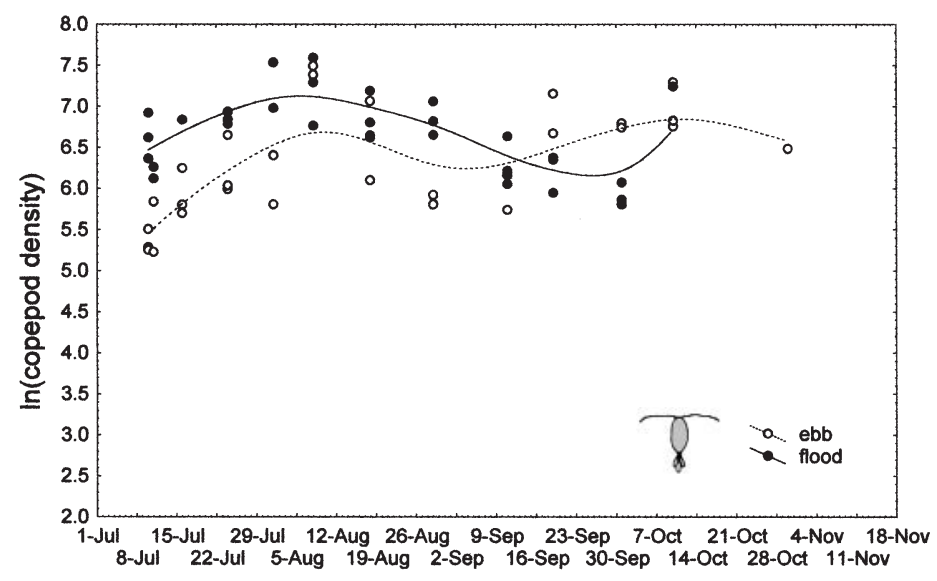

c)

HRW - 1996

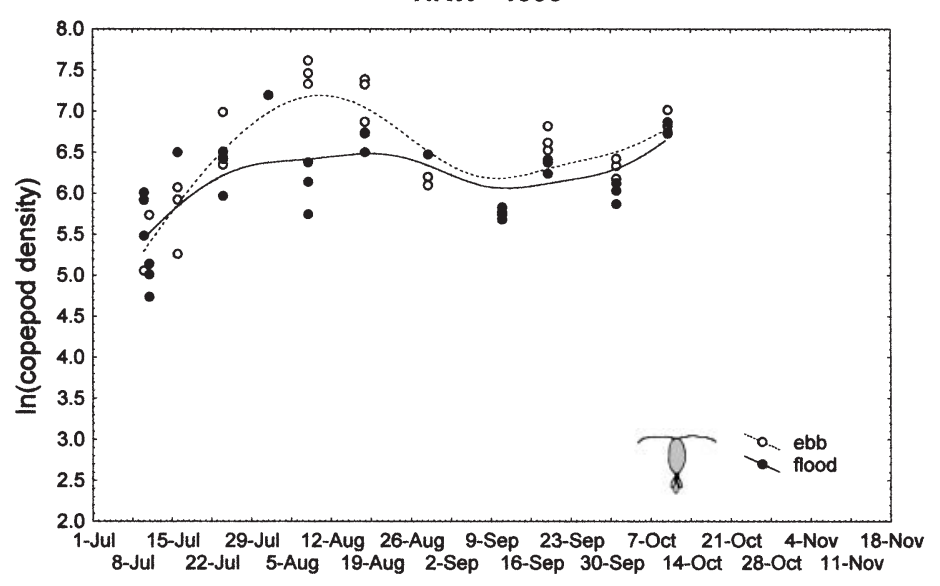

HRC - 1997

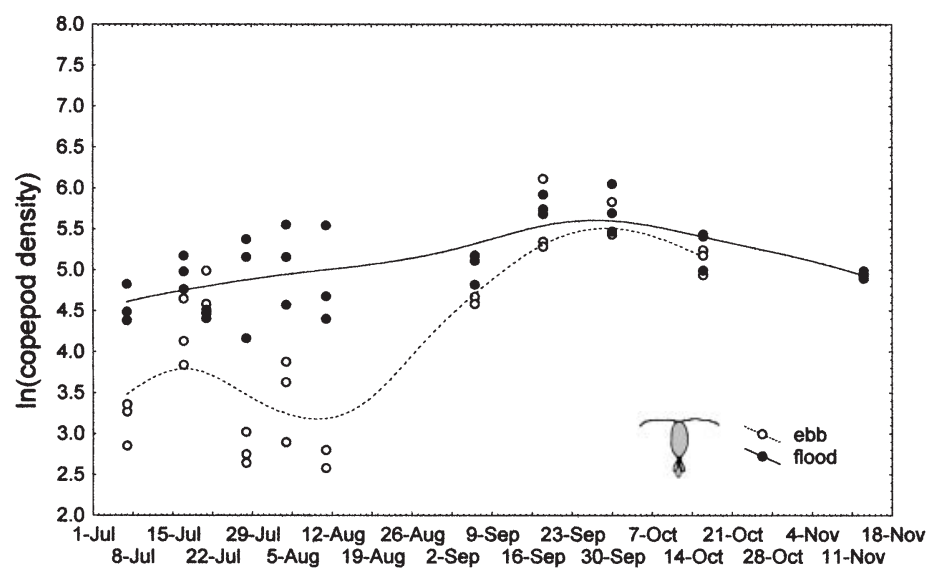

HRW - 1997

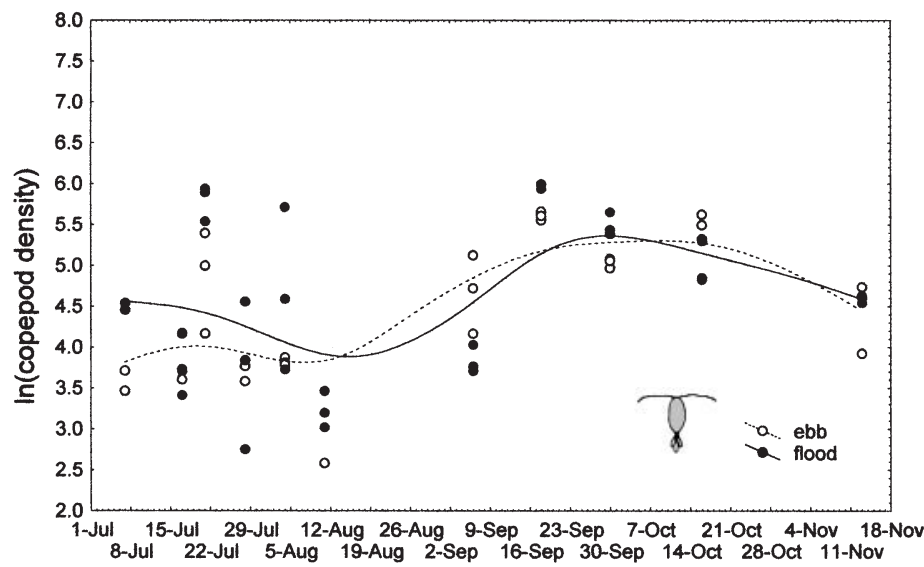

Fig. 6 (continued)

1996 but not in 1997. Changes in abundance within stations between years were significant except for Stns HRE and HRC flood tides between 1996 and 1997 and for Stn HRE ebb tides between 1995 and 1996 (Kolmolgorov-Smirnov and Mann-Whitney $U$-tests, p < 0.01 in significantly different comparisons).

\section{DISCUSSION}

\section{Tidal changes in copepod abundance: potential causes and effects of advected production}

The increases in near-surface copepod abundance within the tidal current but not outside of it support the hypothesis that tidal advection is associated with spatial and temporal changes in food availability to planktivores. Tidal changes in water column properties indicate that colder, saltier water from the Strait of Juan de Fuca is mixed into the San Juan Channel during the flooding tides (Fig. 3b). The source of this water is below the pycnocline in the Juan de Fuca Strait. Copepods were found to be significantly more abundant either near or below the pycnocline. Therefore, it appears that an interaction between animals aggregating near the pycnocline and tidal advection brings copepod aggregations into the surface waters of Cattle Pass from Juan de Fuca. Because estuarine deep circulation in the Juan de Fuca Strait is shoreward at a rate of about $0.1 \mathrm{~m} \mathrm{~s}^{-1}$ (Thomson 1981), any copepods consumed by planktivores could be replenished by advection of animals from the western portions of the Strait.

Within the San Juan Channel, tidal changes in copepod densities appear to be affecting the upper $80 \mathrm{~m}$ of the water column as a whole. There were no detectable depth-differences in copepod densities from shallow versus deep tows in the mixed waters of the southern San Juan Channel. Therefore, it is unlikely that changes in surface copepod densities are caused by a redistribution of copepod densities over depth within the San Juan Channel. If this were so, then samples from downwelling, seaward-moving ebb currents 
should show significantly higher copepod densities in deep tows, whereas samples from upwelling, landward moving flood currents should show significantly higher densities in shallow tows. This was not the case.

Fish distributions and feeding rates, including those of sandlance, have been observed to shift with changes in currents, with fish orienting towards the offshore or upstream side of a topographic feature (e.g. Bray 1981, Johannes 1981, Hobson 1986, Kingsford \& MacDiarmid 1988, Shapiro \& Genin 1993, Noda et al. 1994, Zamon 2000). Most of these studies have explained this fish behavior as a foraging response to fine-scale changes in plankton supply and abundance. In the 2 studies where plankton densities were measured, locations with higher plankton densities were associated with increases in fish feeding rates, gut fullness, or growth (Bray 1981, Anderson \& Sabado 1995). The pattern and magnitude of the density fluctuations observed in the San Juan Channel provide evidence for the fact that tides can change local plankton availability in ways likely to affect foraging success and growth of planktivorous fishes. One can convert the median numerical difference between tides to biomass equivalents with published length-weight equations for copepods. Estimates of the difference in amounts of dry copepod biomass available range between 0.2 and $2.1 \mathrm{mg} \mathrm{m}^{-3}$ (Table 5, for median differences of +47 and +282 copepods, respectively). This range of biomass differences is of the same order of magnitude as differences in plankton availability associated with changes in juvenile kelp perch growth (about $0.25 \mathrm{mg} \mathrm{m}^{-3}$ from Anderson \& Sabado 1995, converting their $1.5 \mathrm{mg} \mathrm{m}^{-3}$ wet weight to dry weight, assuming dry weight of copepods is $\sim 16.9 \%$ of wet weight, see Omori 1969). Juvenile sandlance and herring were frequently observed feeding in the San Juan Channel, and both species contained copepods as well as Coscinodiscus wailesii in their stomachs (O'Reilly 1997, J.E.Z. unpubl. data). There is evidence that the growth of both sandlance and herring can be food-limited (Arrhenius \& Hansson 1999, Robards et al. 1999), so tidal rips and channels may be important foraging sites for planktivorous fishes.

Tidal advection may also make copepods available that might otherwise be less accessible to planktivores. Light levels below the pycnocline depth $(45 \mathrm{~m})$ in Juan de Fuca are low enough ( $<1$ lux; J.E.Z. unpubl. data) to reduce prey intake in sandlance (Porter 1997). This implies that fish could have higher capture rates when feeding near the surface than when feeding on copepod aggregations near or below the pycnocline within the Juan de Fuca Strait. Turbulence associated with currents may also increase encounter rates or make it more difficult for copepods to detect and escape from an attack. a)
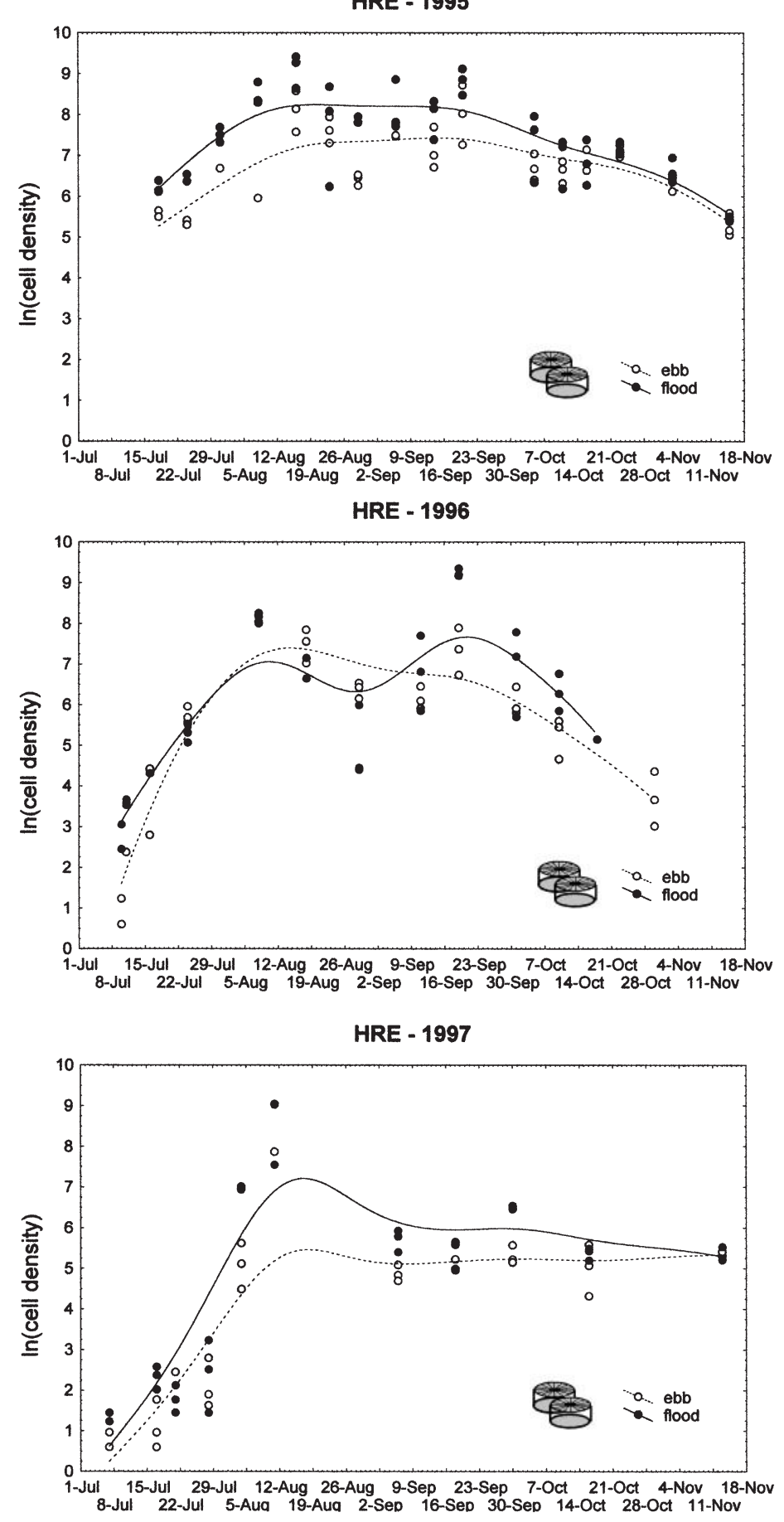

Fig. 7. (Above and following page.) Coscinodiscus wailesii density versus date. (a) Stn HRE, (b) Stn HRC, and (c) Stn HRW. Raw densities of cells per cubic meter were transformed to the natural logarithm of raw densities. Seven tows containing zero values were not plotted on these diagrams; all these tows occurred before 6 August. Best-fit lines were drawn using the least-squares method. The lines help visualize seasonal trends and differences in central tendencies between flood and ebb tides, but they have no other statistical significance 
b)

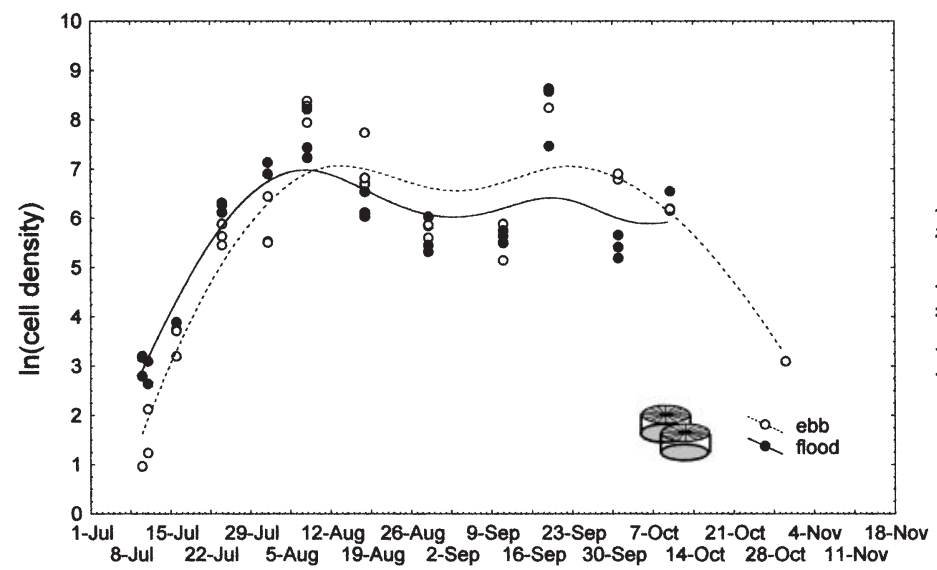

c)

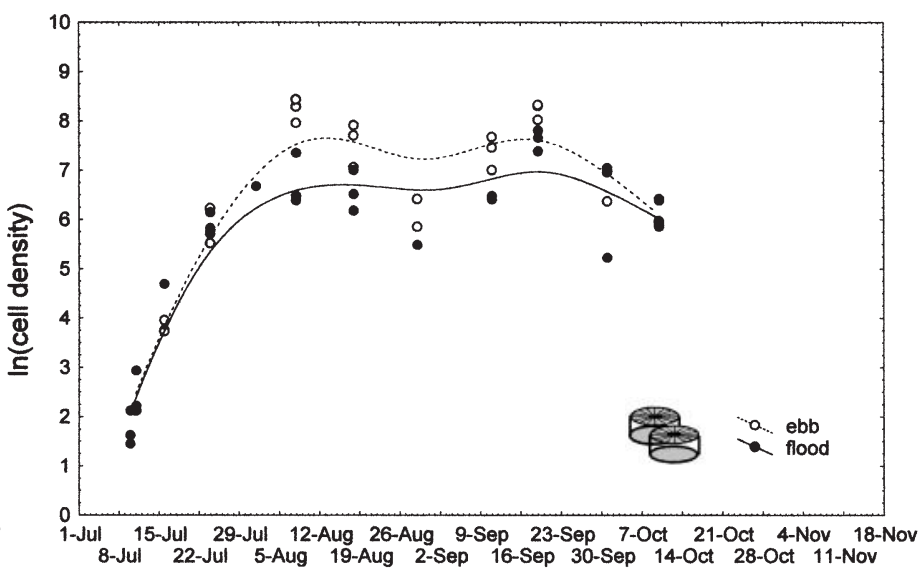

HRC - 1997

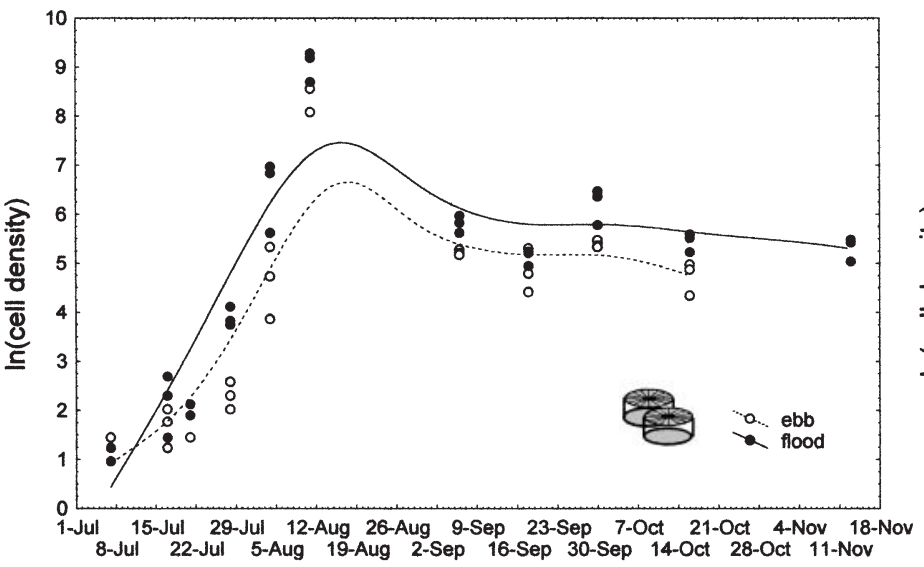

HRW - 1997

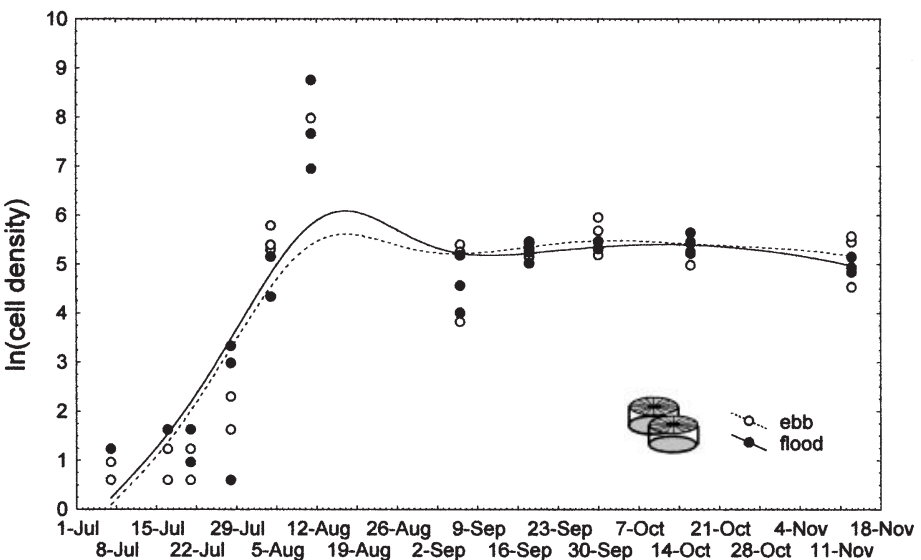

Fig. 7 (continued)

Table 3. Analysis of flood versus ebb differences in Coscinodiscus wailesii densities. Tows with non-zero wire angles were excluded from the analyses. p-values in italics are statistically significant

\begin{tabular}{|lccccc|}
\hline Stn & Year & $\begin{array}{c}\text { No. of valid flood-ebb } \\
\text { comparisons }\end{array}$ & $\begin{array}{c}\text { p-value of } \\
\text { signed-rank test }\end{array}$ & $\begin{array}{c}\text { Median density difference } \\
\text { flood minus ebb } \\
\text { (copepods m }{ }^{-3} \text { ) }\end{array}$ & $\begin{array}{c}\text { Percent of comparisons } \\
\text { where median flood } \\
\text { density }>\text { median ebb density }\end{array}$ \\
\hline HRE & 1995 & 16 & $<0.001$ & +859 & 100 \\
& 1996 & 11 & 0.534 & +22 & 64 \\
HRC & 1997 & 11 & 0.017 & +70 & 82 \\
& 1996 & 12 & 0.638 & +10 & 58 \\
HRW & 1997 & 11 & 0.004 & -132 & 31 \\
& 1996 & 12 & 0.075 & -18 & 36 \\
\hline
\end{tabular}

\section{Extremely large Coscinodiscus wailesii: potential causes and effects of a summer diatom bloom}

The numerical dominance of very large Coscinodiscus wailesii was an unexpected and striking feature of the biology at this site. The contribution of these large cells to primary production and nutrient dynamics here is unknown, but this diatom was consistently found in the stomachs of Pacific sandlance (O'Reilly 1997, Porter 1997, J.E.Z. unpubl. data) and Pacific herring (J.E.Z. unpubl. data). This is an interesting observation because large cells may, in some cases, provide a sig- 
Table 4. Plankton densities per cubic meter in stratified water. Tows were collected from Stn NS-2 at slack high tide, when stratified water was present

\begin{tabular}{|lcc|}
\hline \multirow{2}{*}{ Plankton type } & \multicolumn{2}{c|}{ Tow type } \\
& Pycnocline to surface & 95 $\mathrm{m}$ to surface \\
\hline Copepods & 319.8 & 591.6 \\
& 331.0 & 657.7 \\
& 269.9 & 645.7 \\
& 444.1 & 578.6 \\
Coscinodiscus wailesii & 184.9 & 624.9 \\
& 236.8 & 168.8 \\
& 247.5 & 191.1 \\
& 222.7 & 182.5 \\
& 164.8 & 262.5 \\
& \\
\hline
\end{tabular}

nificant source of nutrition to fish (Horn 1989). Although $C$. wailesii is known to occur in Puget Sound (see Gran \& Angst 1931), I found no recently published reports of blooms of this diatom in the Strait of Georgia, Juan de Fuca, or Puget Sound regions. Perhaps this is because most primary productivity studies exclude particles larger than $100 \mu \mathrm{m}$ (e.g. St. John \& Pond 1992). I was unable to find mention of large diatoms in zooplankton studies; this is surprising because $C$. wailesii were such an obvious component of the plankton tows.

Tidal mixing in the Juan de Fuca-Strait of Georgia region is known to increase nutrient concentrations (primarily nitrate) in surface waters (e.g. Parsons et al. 1981, 1983, St. John \& Pond 1992, Mackay \& Harrison 1997); similar nutrient increases have been reported in other geographic locations (e.g. Wolanski et al. 1988).
Local maintenance of higher nutrient concentrations by tidal mixing may explain the extended nature of the Coscinodiscus wailesii blooms and the large cell sizes observed in Cattle Pass. The bloom continued well past the April spring bloom that occurs in the stratified waters of the Strait of Georgia (cf. Yin et al. 1997). Although nutrient concentrations were not measured in this study, the tidal fluctuations in temperature and salinity profiles show that deep water is mixed into the San Juan Channel and therefore is likely to maintain relatively high nitrate concentrations throughout the summer. The abilities of $C$. wailesii to survive as resting cells in the dark (Nagai et al. 1995a) and to attain large size through vegetative growth (Nagai et al. 1995b) may be adaptations for living in areas of great turbulence, where nutrient concentrations are high but cells may be mixed into low-light environments for long periods of time.

Blooms of large Coscinodiscus wailesii have been reported in the Seto Inland Sea of Japan (Manabe \& Ishio 1991) and the German Bight (Rick \& Dürselen 1995), where this species can account for up to $90 \%$ of phytoplankton biomass retained on $0.2 \mu \mathrm{m}$ filters. Given cell sizes observed in Cattle Pass $(\sim 190 \mu \mathrm{m}$ radius $\times 220 \mu \mathrm{m}$ height), I used Strathmann's (1969) equations to estimate that 1 cell contains about $1.5 \mathrm{\mu g}$ of carbon; equivalently, $6.6 \times 10^{2}$ cells contribute approximately $1 \mathrm{mg}$ of carbon. Densities of $>10^{3}$ cells $\mathrm{m}^{-3}$ were not uncommon in this study. At the densities observed in Cattle Pass, water columns $1 \mathrm{~m} \times 1 \mathrm{~m} \times$ $100 \mathrm{~m}$ deep would contain almost $1 \mathrm{~g}$ of carbon in $C$. wailesii biomass. Because of this diatom's potential importance to the carbon budget and food web, the distribution, seasonal cycle, and population dynamics of $C$. wailesii deserve further investigation.

Table 5. Estimates of median tidal differences in copepod biomass. Prosome lengths of 25 copepods of each taxonomic category were measured with an ocular micrometer. Individuals were from preserved samples collected on 8 August 1996 and 11 August 1997 at Stn HRE. Data are reported as means \pm SE. Relative numerical abundances of different copepod types were calculated using all flood tides at Stn HRE. The numerical contribution to median differences was estimated by multiplying median differences from Table 2 by the relative abundance for each copepod category. Biomass was estimated using mean prosome lengths in length-dry weight equations as follows: Pseudocalanus, $W=11.9 L^{3.64}$ (Corkett \& McLaren 1978); Paracalanus, $W=10^{-8.451} L^{3.128}$ (Liang \& Uye 1996); Corycaeus anglicus, $W=10^{-7.17} L^{2.8}$ (Chisholm \& Roff 1990); Acartia spp., $W=12.37 L^{3.628}$ (Durbin \& Durbin 1978); other calanoids, $W=2.0 L^{3.92}$ (Peterson 1979). In these equations, $W=$ dry weight in $\mu$ g and $L=$ prosome (cephalothorax) length in mm, except for Paracalanus and Corycaeus, for which $L=$ prosome length in $\mu \mathrm{m}$

\begin{tabular}{|lcccccc|}
\hline & Year & Pseudocalanus & Paracalanus & $\begin{array}{c}\text { Corycaeus } \\
\text { anglicus }\end{array}$ & $\begin{array}{c}\text { Acartia } \\
\text { spp. }\end{array}$ & $\begin{array}{c}\text { Other } \\
\text { calanoid }\end{array}$ \\
\hline Mean prosome length (mm) & 1996 & 0.92 & 0.70 & 0.87 & 0.84 & 1.76 \\
& 1997 & 0.92 & 0.76 & 0.56 & 0.88 & 1.10 \\
Relative abundance (\%) & 1996 & 55.2 & 25.3 & 7.2 & 4.3 & 7.9 \\
& 1997 & 23.9 & 36.1 & 21.9 & 0.07 & 0.08 \\
Dry biomass contribution $\left(\mathrm{mg} \mathrm{m}^{-3}\right)$ & 1996 & 1.37 & 0.20 & 0.07 & 0.01 \\
& 1997 & 0.10 & 0.06 & 0.01 & 0.01 \\
\hline
\end{tabular}


a)

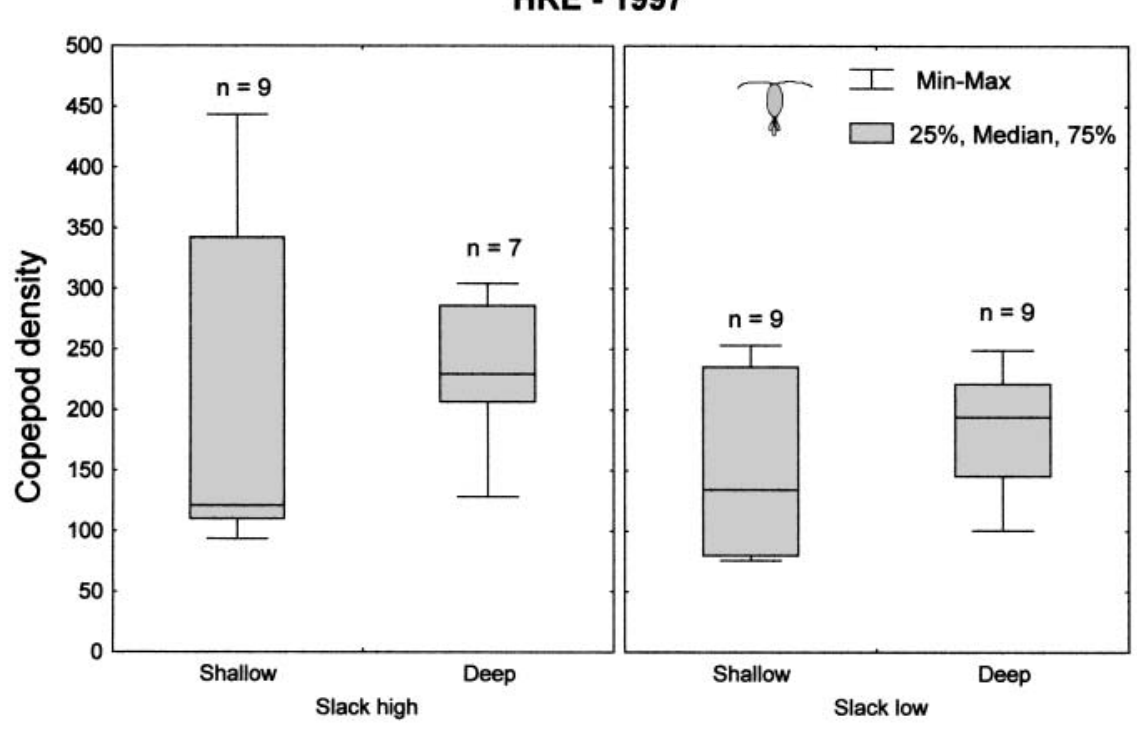

b)

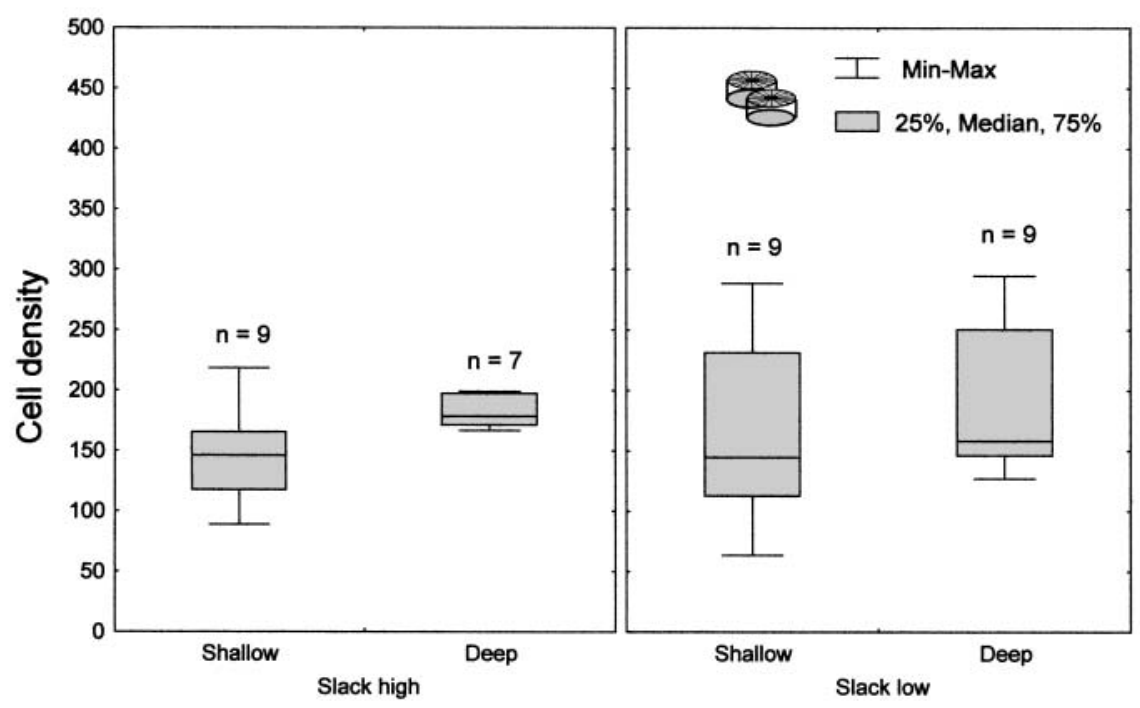

Fig. 8. Deep versus shallow plankton densities in mixed water. (a) Copepods and (b) Coscinodiscus wailesii. Shallow tows were collected from $25 \mathrm{~m}$ to the surface, deep tows were collected from $80 \mathrm{~m}$ to the surface

\section{The general importance of tidally advected production}

Advected nutrients and secondary production have been recognized as important factors which may influence food web dynamics in island archipelagos (Uda \& Ishino 1958, Johannes \& Gerber 1974, Noda et al. 1992, Polis et al. 1997). Tidal currents linking sources of nutrients and plankton to surface waters may act as 'pumps' that rapidly transfer energy to higher trophic levels via planktivorous fishes (this study) or other planktivores (cf. Hunt et al. 1998, Leichter et al. 1998). Tide-topography interactions alter planktivorous fish distribution and behavior in space and time (Bray 1981,
Hobson 1986, Shapiro \& Genin 1993, Noda et al. 1994, Zamon 2000), which would explain why predators feeding on planktivorous fish also exhibit strong tidal patterns in their foraging behavior (e.g., Braune \& Gaskin 1982, Safina \& Burger 1988, Zamon 2000, 2001). Tidal currents provide a mechanism to supply what oceanographers call 'auxiliary energy' (Mann \& Lazier 1996) and terrestrial ecologists call 'allochthonous energy' (Polis et al. 1997) to local food webs. The predictability of such energy subsidies among years (this study) may help explain the exceptional species diversity and abundance of complex topographic environments in general, and of the San Juan and Gulf Island region in particular. 
Appendix 1. Station locations for hydrographic profiles and net tows

\begin{tabular}{|lcccl|}
\hline Stn & Latitude (N) & Longitude $(\mathrm{W})$ & Water depth $(\mathrm{m})$ & \\
\hline NS-1 & $48^{\circ} 25.000^{\prime}$ & $122^{\circ} 56.500^{\prime}$ & 95 & Description \\
NS-2 & $48^{\circ} 25.700^{\prime}$ & $122^{\circ} 57.000^{\prime}$ & 105 & Juan de Fuca \\
NS-3 & $48^{\circ} 27.000^{\prime}$ & $122^{\circ} 57.000^{\prime}$ & 94 & Juan de Fuca \\
NS-4 & $48^{\circ} 29.500^{\prime}$ & $122^{\circ} 57.300^{\prime}$ & Cattle Pass, north of Whale Rocks \\
NS-5 & $48^{\circ} 32.000^{\prime}$ & $122^{\circ} 56.000^{\prime}$ & 100 & San Juan Channel, Rock Point \\
GB1-a & $48^{\circ} 28.700^{\prime}$ & $122^{\circ} 59.400^{\prime}$ & 30 & San Juan Channel, Fisherman Bay \\
GB1-b & $48^{\circ} 28.700^{\prime}$ & $122^{\circ} 59.200^{\prime}$ & 40 & Western Griffin Bay, shelf \\
GB1-C & $48^{\circ} 28.700^{\prime}$ & $122^{\circ} 58.700^{\prime}$ & Western Griffin Bay, shelf \\
GB1-d & $48^{\circ} 28.700^{\prime}$ & $122^{\circ} 58.400^{\prime}$ & 80 & Central Griffin Bay, central basin \\
GB1-e & $48^{\circ} 28.700^{\prime}$ & $122^{\circ} 57.700^{\prime}$ & 120 & Eastern Griffin Bay, central basin \\
GB1-f & $48^{\circ} 28.700^{\prime}$ & $122^{\circ} 57.200^{\prime}$ & 100 & San Juan Channel, west side \\
HRW & $48^{\circ} 28.280^{\prime}$ & $122^{\circ} 57.950^{\prime}$ & San Juan Channel, east side \\
HRC & $48^{\circ} 28.300^{\prime}$ & $122^{\circ} 57.600^{\prime}$ & 54 & Near Harbor Rock \\
HRE & $48^{\circ} 32.000^{\prime}$ & $122^{\circ} 56.000^{\prime}$ & 137 & San Juan Channel, west side \\
& & & 96 & San Juan Channel, east side \\
\hline
\end{tabular}

Acknowledgements. Financial support for this work was provided by the Holcomb Scholarship (UC-Irvine), a grant from the National Council for Air and Stream Improvement, Frank M. Chapman Awards (American Museum of Natural History), Stafford Loan Program, and an EPA STAR Graduate Fellowship (EPA \#U915017-01-1). The author gratefully acknowledges long-term logistical support from George and Peggy Hunt; Friday Harbor Marine Laboratories staff, faculty and students; and the Cape San Juan community of San Juan Island. The cheerful assistance of Lance Batch, Heather Revilee, and Danney Grae aboard the RV 'Chaika' and in the laboratory was essential for completion of this project. Shonali Chandy, Eugene Kozloff, and Elizabeth Venrick helped with plankton identification. Suggestions from George Hunt, Loren Haury, Brad Hawkins, Bob Josephson, Dave Mackas, and 2 anonymous reviewers greatly improved this manuscript.

\section{LITERATURE CITED}

Alldredge AL, Hamner WM (1980) Recurring aggregation of zooplankton by a tidal current. Estuar Coast Mar Sci 10: 31-37

Anderson TW, Sabado BD (1995) Correspondence between food availability and growth of a planktivorous temperate reef fish. J Exp Mar Biol Ecol 189:65-76

Arrhenius F, Hansson S (1994) In situ food consumption by young-of-the-year Baltic Sea herring Clupea harengus: a test of predictions from a bioenergetics model. Mar Ecol Prog Ser 110:145-149

Arrhenius F, Hansson S (1999) Growth of Baltic Sea young-ofthe-year herring Clupea harengus is resource limited. Mar Ecol Prog Ser 191:295-299

Batty RS, Blaxter JHS, Richard JM (1990) Light intensity and the feeding behavior of herring, Clupea harengus. Mar Biol 107:383-388

Braune BM, Gaskin DE (1982) Feeding ecology of nonbreeding populations of larids off Deer Island, New Brunswick. Auk 99:67-76

Bray RN (1981) Influence of water currents and zooplankton densities on daily foraging movements of blacksmith, Chromis punctipinnis, a planktivorous reef fish. Fish Bull US 78:829-841

Brown RGB, Barker SP, Gaskin DE (1979) Daytime surface swarming by Meganyctiphanes norvegica (M. Sars) (Crustacea, Euphausiacea) off Brier Island, Bay of Fundy. Can J Zool 57:2285-2291

Chisholm LA, Roff JC (1990) Size-weight relationships and biomass of tropical neritic copepods off Kingston, Jamaica. Mar Biol 106:71-77

Corkett CJ, McLaren IA (1978) The Biology of Pseudocalanus. Adv Mar Biol 15:2-231

Durbin EG, Durbin AG (1978) Length and weight relationships of Acartia clausi from Narragansett Bay, R.I. Limnol Oceanogr 23:958-969

Field LJ (1988) Pacific sandlance, Ammodytes hexapterus, with notes on related Ammodytes species. In: Wilimovsky NJ, Incze LS, Westrheim SJ (eds) Species synopses: life histories of selected fish and shellfish of the northeast Pacific and Bering Sea. Washington Sea Grant Program/Fisheries Research Institute, University of Washington, Seattle, p 16-33

Gagnon M, LaCroix G (1982) The effects of tidal advection and mixing on the statistical dispersion of zooplankton. J Exp Mar Biol Ecol 56:9-22

Golden Software I (1994) Surfer for Windows. Golden Software, Inc, Golden

Gran HH, Angst EC (1931) Plankton diatoms of Puget Sound. Publ Puget Sound Biol Sta 7:417-519

Haegele CW (1997) The occurrence, abundance, and food of juvenile herring and salmon in the Strait of Georgia, British Columbia in 1990 to 1994. Can Manu Rep Fish Aquat Sci 2390

Hamner WM, Hauri IR (1977) Fine-scale surface currents in the Whitsunday Islands, Queensland, Australia: effect of tide and topography. Aust J Mar Freshw Res 28:333-359

Hobson ES (1986) Predation on the Pacific sandlance, Ammodytes hexapterus (Pisces: Ammodytidae), during the transition between day and night in southeastern Alaska. Copeia 1:223-236

Horn MH (1989) Biology of marine herbivorous fishes. Oceanogr Mar Biol Annu Rev 27:167-272

Hunt GL Jr, Russell RW, Coyle KO, Weingartner T (1998) Comparative foraging ecology of planktivorous auklets in relation to ocean physics and prey availability. Mar Ecol Prog Ser 167:241-259

Hunt GL Jr, Mehlum F, Russell RW, Irons D, Decker MB, Becker PH (1999) Physical processes, prey abundance, and the foraging ecology of seabirds. 22nd International 
Ornithological Congress, Birdlife South Africa, Durban, South Africa

Johannes RE (1981) Words of the lagoon. University of California Press, Berkeley

Johannes RE, Gerber R (1974) Import and export of net plankton by an Eniwetok coral reef community. 2nd International Coral Reef Symposium, Brisbane

Kingsford MJ, MacDiarmid AB (1988) Interrelations between planktivorous reef fish and zooplankton in temperate waters. Mar Ecol Prog Ser 48:103-117

Kingsford MJ, Wolanski E, Choat JH (1991) Influence of tidally induced fronts and Langmuir circulations on distribution and movements of presettlement fishes around a coral reef. Mar Biol 109:167-180

Leichter JJ, Shellenbarger G, Genovese SJ, Wing SR (1998) Breaking internal waves on a Florida (USA) coral reef: a plankton pump at work? Mar Ecol Prog Ser 166:83-97

Lewis MG, Sharpe FA (1987) Birding in the San Juan Islands. The Mountaineers, Seattle

Liang D, Uye S (1996) Population dynamics and production of the planktonic copepods in a eutrophic inlet of the Inland Sea of Japan. III. Paracalanus sp. Mar Biol 127:219-227

Mackay DL, Harrison PJ (1997) Nitrogenous nutrient sources and sinks in the Juan de Fuca Strait/Strait of Georgia/ Puget Sound estuarine system: assessing the potential for eutrophication. Estuar Coast Shelf Sci 44:1-21

Manabe T, Ishio S (1991) Bloom of Coscinodiscus wailesii and DO deficit of bottom water in Seto Inland sea. Mar Pollut Bull 23:181-184

Mann KH, Lazier JRN (1996) Dynamics of marine ecosystems: biological-physical interactions in the oceans. 2nd edn. Blackwell Scientific Publications, Boston

Nagai S, Hori Y, Manabe T, Imai I (1995a) Morphology and rejuvenation of Coscinodiscus wailesii Gran (Bacillariophyceae) resting cells found in bottom sediments of Harima-Nada, Seto Inland Sea, Japan. Nippon Suisan Gakkaishi 61:175-185

Nagai S, Hori Y, Manabe T, Imai I (1995b) Restoration of cell size by vegetative cell enlargement in Coscinodiscus wailesii (Bacillariophyceae). Phycologia 34:533-535

Noda M, Kawabata K, Gushima K, Kakuda S (1992) Importance of zooplankton patches in foraging ecology of the planktivorous reef fish Chromis chrysurus (Pomacentridae) at Kuchinoerabu Island, Japan. Mar Ecol Prog Ser 87: 251-263

Noda M, Gushima K, Kakuda S (1994) Local prey search based on spatial memory and expectation in the planktivorous reef fish, Chromis chrysurus (Pomacentridae). Anim Behav 47:1413-1422

Omori M (1969) Weight and chemical composition of some important oceanic zooplankton in the North Pacific Ocean. Mar Biol 3:4-10

O'Reilly KM (1997) Sunrise and sunset gut volume comparisons, field observations and predator avoidance of Pacific sandlance, Ammodytes hexapterus, at San Juan Island, Washington. School of Fisheries, University of Washington, Seattle

Parsons TR, Stronach J, Borstad GA, Louttit G, Perry RI (1981) Biological fronts in the Strait of Georgia, British Columbia, and their relation to recent measurements of primary productivity. Mar Ecol Prog Ser 6:237-242

Parsons TR, Perry RI, Nutbrown ED, Hsieh W, Lalli CM (1983) Frontal zone analysis at the mouth of Saanich Inlet, British Columbia, Canada. Mar Biol 73:1-5

Editorial responsibility: Michael Landry (Contributing Editor), Honolulu, Hawaii, USA
Peterson WT (1979) Life history and ecology of Calanus marshallae Frost in the Oregon upwelling zone. Oregon State University, Corvallis

Polis GA, Anderson WB, Holt RD (1997) Toward an integration of landscape and food web ecology: the dynamics of spatially subsidized food webs. Annu Rev Ecol Syst 28:289-316

Porter SM (1997) The effect of light on Pacific sand lance, Ammodytes hexapterus, feeding success and its implications for sand lance schools inhabiting Griffin Bay, San Juan Island, Washington, Seattle. School of Fisheries, University of Washington, Seattle

Rick HJ, Dürselen CD (1995) Importance and abundance of the recently established species Coscinodiscus wailesii Gran \& Angst in the German Bight. Helgol Meeresunters 49:355-374

Robards MD, Willson MF, Armstrong RH, Piatt JF (1999) Sand lance: a review of biology and predator relations and annotated bibliography. Res Pap PNW-RP-521, USDA, Forest Service, Pacific Northwest Research Station, Portland

Safina C, Burger J (1988) Ecological dynamics among prey fish, bluefish, and foraging common terns in an Atlantic coastal system. In: Burger J (eds) Seabirds and other marine vertebrates: competition, predation, and other interactions. Columbia University Press, New York, p 93-165

Shapiro DY, Genin A (1993) Feeding whorl induced by strong current in a planktivorous reef fish. Copeia 1993:542-545

St. John MA, Pond S (1992) Tidal plume generation around a promontory: effects on nutrient concentrations and primary productivity. Cont Shelf Res 12:339-354

St. John MA, Harrison PJ, Parsons TR (1992) Tidal wakemixing: localized effects on primary production and zooplankton distributions in the Strait of Georgia, British Columbia. J Exp Mar Biol Ecol 164:261-274

Strathmann RR (1969) Estimating the organic carbon content of phytoplankton from cell volume or plasma volume. Limnol Oceanogr:411-418

Thomson RE (1981) Oceanography of the British Columbia Coast. Can Spec Publ Fish Aquat Sci 56:1-291

Uda M, Ishino M (1958) Enrichment patterns resulting from eddy systems in relation to fishing grounds. J Tokyo Univ Fish 44:105-129

Winslade P (1974) Behavioural studies on the lesser sandeel Ammodytes marinus (Raitt) II. The effect of light intensity on activity. J Fish Biol 6:577-586

Wolanski E, Hamner WM (1988) Topographically controlled fronts in the ocean and their biological influence. Science 241:177-181

Wolanski E, Drew E, Abel KM, O'Brien J (1988) Tidal jets, nutrient upwelling, and their influence on the productivity of the alga Halimeda in the Ribbon Reefs, Great Barrier Reef. Estuar Coast Shelf Sci 26:169-201

Yin K, Harrison PJ, Goldblatt RH, St. John MA, Beamish RJ (1997) Factors controlling the timing of the spring bloom in the Strait of Georgia estuary, British Columbia. Can J Fish Aquat Sci 54:1985-1995

Zamon JE (2000) The influence of tidal currents on plankton densities and energy flow to seals, seabirds, and schooling fishes in the San Juan Islands, Washington, USA. PhD thesis, University of California, Irvine, p 1-181

Zamon JE (2001) Seal predation on salmon and forage fish schools as a function of tidal currents in the San Juan Islands, Fish Oceanogr 10:353-366

Submitted: December 28, 1999; Accepted: March 28, 2001

Proofs received from author(s): January 14, 2002 